The Use and Importance of External Sources of Knowledge in the Software Development Process

Esbjörn Segelod and Gary Jordan
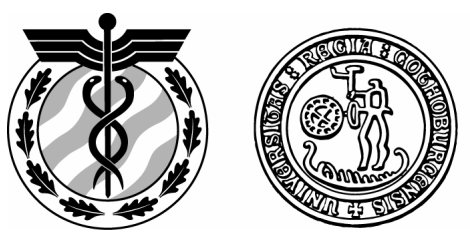


\title{
The Use and Importance of External Sources of Knowledge in the Softw are Development Process ${ }^{1}$
}

\begin{abstract}
Partnerships and external knowledge acquisition have become important means for gaining access to the increasing number of technologies needed for the development of more advanced products especially in emerging and dynamic industries. A good example is the fast expanding computer software industry where linkages are many and important. This is an empirical study of linkages and their relative importance in different stages of the software development process. The amount of new knowledge generated though different sources and differences between different types of software, such as packaged and customised software, are analysed. The analysis draws on case studies of 92 mostly European software projects, and a pilot study of four projects. It shows the length, type, and relative importance of 718 linkages in the software development process. The data collected shows that there are important differences between tangible hardware and software projects when it comes to the importance of the various linkages and the knowledge acquired
\end{abstract}

Keywords: Computer software firms; external knowledge acquisition; industrial networks; product development; software development processes; software industry; software projects.

JEL-code: M10, O22

School of Economics and Commercial Law, Göteborg University

P.O. Box 610, SE 40530 Göteborg, SWEDEN

Esbjörn Segelod, tel. +4616 15 51 38, e-mail: esbjorn.segelod@mdh.se

(C) Esbjörn Segelod \& Gary Jordan 2002

\footnotetext{
1 Acknowledgements: The authors wish to thank the many software firm project managers who provided the information that has been used for this report. We also appreciate the support provided by the Ruben Rausing Foundation that was used in the study.
} 


\section{Introduction}

New innovations have come to combine an increasing number of technologies at the same time as increased competition has forced firms to shorten product development duration. This has made it more and more important for firms to focus on developing their core competencies, outsource peripheral parts of their business, and to be able to identify and to acquire knowledge from external sources to develop new products whenever this is cheaper and can shorten product development duration. Such external knowledge can be embedded in products or transferred from consultants and other types of cooperative partners.

The increasing use of external sources of technology is well documented (Granstrand et al. 1992; Dodgson, 1994; Jones et al., 2000). This varies by industry geographically but the trend is obvious and world-wide (Roberts, 1995; Hagedoorn, 2002). Acquiring new knowledge through external sources makes it possible to develop new products faster, and to deploy new products and knowledge faster. However, a too far driven strategy of out-sourcing can also decrease the ability of firms to maintain and upgrade their internal capabilities. It can decrease their ability to identify the value of external knowledge, form linkages to acquire, integrate and make commercial use of it, i.e. what Cohen and Levinthal (1990) term 'absorptive capacity'.

The increasing use of out-sourcing has created a rapidly growing market for the staffing industry and contingent work (Matusik and Hill, 1988). Easier excess to external knowledge has made it more common to hire people for a specific development project, rather than for permanent company positions. This lessens long-term commitments and increases flexibility. Project-based organizations are common in for instance the film industry, and are also used by high-tech firms which have chosen to focus on being good at system integration and relying on external sources and temporarily employing specialists to be able to carry out complex projects combining many different technologies, so called system companies (Segelod, 1995; Bonaccorsi et al., 1996; 1999).

External sourcing exists in all types of product development. Håkansson $(1989 ; 1990)$ in a study of 123 small and medium sized Swedish companies found that about $30 \%$ of all product development projects were carried out in cooperation with customers, suppliers and other partners. Roughly about half the resources these firms invested in product development were committed to projects in which external partners were of substantial importance and " $t]$ he highest profit and the highest growth were obtained by companies having about a $50 \%$ external share in development" (Håkansson, 1990: 373).

It is generally assumed that smaller firms are more dependent on external knowledge acquisition, than large firms (Rothwell and Dodgson, 1991; Macdonald, 1995; 1998), as large firms have excess to a greater variety of knowledge in-house. In a questionnaire-based study of 100 innovative small and medium-sized enterprises (SMEs) in the UK Beesley and Rothwell (1987) found that " $89 \%$ of the firms studied had a significant link in at least one of the following areas: contracting-out R\&D; joint-ventures; marketing relationships; manufacturing relationships; links with educational establishments; other public sector bodies and research associations" (Rothwell and Dodgson, 1991: 128). In a similar study by Parolini (1990) of 80 small high-tech Italian firms " $63 \%$ of the firms engaged in agreements with other companies" (Rothwell and Dodgson, 1991: 128). 
Furthermore, a study of 12 leading technology-based SMEs in Britain, Denmark, Holland and Ireland showed that all firms had developed a variety of often very strong links with universities, research institutes, other industrial companies, suppliers and customers. They were also increasingly developing technology strategies just as sophisticated as those found in large enterprises (Rothwell and Dogson, 1991), and the most important sources of external knowledge were, as also other studies such as Håkansson (1989) have found, suppliers and customers.

Studies of American companies have shown that technological linkages are highest in emerging and dynamic industries (Auster, 1992; Hagedoorn, 1993). In a fast changing heterogeneous environment it becomes more important to form alliances and use external sources to acquire state-of-art technologies, because no single firm can in such an environment possess all the knowledge required to meet customers' need. It has to, in part, rely on external sources and develop its ability to learn through these sources to develop new products, something that usually is a very time consuming process (Nonaka and Takeuchi, 1995). Analysing the consequences of such a heterogeneous environment Hagedoorn (1993) points out the computer software industry as the best example of an industry where access to the knowledge of external partners is of special importance to be able to develop more advanced software applications as these typically integrate many different technologies.

There is a long tradition of research on tangible product innovations that are based on physical sciences and engineering, but still very little research on software development process from an innovation perspective. It has been shown that firms seldom innovate on the basis of internal resources only. Much of the knowledge often derives from external sources, and sometimes also the product idea.

"In most industries, no single firm commands a majority of the resources available for research, nor can any one firm respond to more than a portion of the needs or problems requiring original solutions. It is not surprising, therefore, to find that most of the ideas successfully developed and implemented by any firm come from outside that firm." (Utterback, 1994: 30)

External linkages are important to tangible product development and have been scrutinized in many different studies e.g. Utterback (1974), Klein and Rosenberg (1986), and Håkansson (1989). There are case studies, interview-based studies, and statistical questionnaire-based studies, but very few studies of external linkages in software development projects. The question is only briefly mentioned in a McKinsey's interview-based study (Hoch et al., 2000) based on interviews in 94 software product and service companies. Without giving any numerical support they claim the following for so-called 'web shapers' (Hagel, 1999), i.e. companies like Microsoft, and SAP, that help partners enhance the use of their systems, Windows and SAP R/3:

"In our survey, we found that the successful software companies spent an average 1.4 percent of their revenues on training their partners, 75 percent more than the less successful companies. In 1997, for instance, Microsoft had invested \$600 million annually on training, certification, and support of partner developers, according to a report by the U.S. securities firm Everen. ... The successful companies had, on average, more than four times more partners than the less successful players." (Hoch et al., 2000: 182) 
However, partnering to increase the number of users of an operative or enterprise information system is a specific form of linkages. Hoch et al., as most studies of knowledge acquisition, studied the question from a company perspective. Far less is known of the use of external sources of knowledge from a project perspective, and very little of the software development process from idea to commercialisation. Still, software development constitutes an increasing part of the total R\&D-spending, and drives much of today's economy. At the same time one can observe that software is an intangible product consisting of "nothing but pure knowledge in codified form" (Hoch et al., 2000: 6). See also Beatjer (1998). One can therefore ask oneself whether the knowledge that research has uncovered about tangible product development processes applies also to intangible products such as software. These observations and the lack of empirical research in the area raise the question whether software is different from tangible product development projects when it comes to the sources and usage of external knowledge in the product development process, and if that is the case, what the consequences would be for innovation theory.

Having observed the importance of external knowledge acquisition in major ventures in new areas (Segelod, 1995), the abundant use of linkages in the computer software industry to develop new software, and the lack of innovation research on software development processes, the authors of this paper made four pilot case studies of knowledge acquisition and development in four smaller Swedish software companies. These cases studies included both one very profitable system company, and a software security firm, which for reason of security minimized its use of external linkages to develop its security solutions. The cases differed significantly in their knowledge development strategy and the importance they attached to various sources of new knowledge. This made it necessary to extend these case studies to a larger number of software development projects and firms to be able to understand the use and importance of various external sources of new knowledge in the industry and the knowledge strategies applied.

Thus the purpose of this study can be formulated as to describe and analyse the importance of external sources of knowledge in computer software development projects. The study will map which external actors are involved in the development of software and when they are involved, the importance the project managers interviewed ascribed to them, the amount of new knowledge generated though these sources, and differences between different types of software, such as packaged and customized software. The analysis is based on 718 linkages identified through interviews with project managers of 92 mostly European software projects.

The structure of the paper is as follows: first, an account of the research methodology; then, the model used to collect information on the use and importance of different sources of external knowledge; and next a description of the differences between hardware and software development. In Sections 5-7 descriptions are given of the linkages used and the importance attached to these linkages in the different phases of the software development project studied. Next, in Section 8, a regression analys is of the factors claimed to determine the use of external sources of knowledge is given. Section 9 contains an analysis of the differences between software developed for a single client versus a mass market, and in Section 10 a qualitative analysis is given of the difference between software projects using more or less external linkages. The paper closes with a short summary of the results of the study. There is also an Appendix with a few observations on cooperation between small and large firms and the location of cooperative partners. 


\section{Research Methodology}

This paper is based on a sample of 92 software development projects and a pilot study of four projects supplemented with 35 additional company interviews. Thirty-one of these 92 projects were carried out in Sweden, 52 in other European countries, and the remaining nine in nonEuropean Anglo-Saxon countries and Peru. See Table 1. The software projects studied represent a wide range of software programs and companies. The initial Swedish companies were chosen from a list of Swedish IT-companies supplied by an industry organization. However, as it was not possible to know in advance if the company in fact had developed an appropriate software program, or were only selling and implementing software packages, hence it was not possible to make a randomised sample. Instead, companies were selected sequentially from the industry list so as to represent a wide range of sizes and product types. These were checked to determine that they actually developed software and if so they were contacted through a senior manager or project manager and asked to select a recent software development project for the study. In a few of the later cases direct contact was made with managers without reference to the industry list. The non-Swedish cases were chosen by exchange students from the country in question. Also in these cases the companies contacted preferred to choose important and successful projects. This sampling procedure makes the sample biased towards successful projects. On a scale 1 to 5 the average respondents judged the overall success of their project to be 4.19; median 4. Similarly, the extent to which company profitability has been enhanced by the project receives an average value of 3.65; median 4 . The number of linkages does not significantly vary between cases from different countries and cultural areas. See Appendix.

The data collection has been a long drawn out process. It started in 1996 with a series of 15 interviews in Swedish computer software firms intended to give an overview of their products, markets, finance, and problems. A year later we started to carry out case studies of knowledge acquisition and development in four smaller Swedish software firms and their software development projects. These fur case studies initiated the present study and were used to develop the interview protocol used in this study.

The interviews using the new interview protocol started in 1999 and ended in the autumn of 2001. The interviews were made by students as part of a five or ten weeks master level course on business development strategies with special reference to the computer software industry. The course gave them the theoretical background to the questions in the interview protocol. Most of the questions required responses based on a specific software development project and thus the unit of analysis was the project. One set of questions was directed to the knowledge handling strategy at the company level to collect data from that perspective. In all, 133 interviews have been made in 115 groups of companies developing software programs.

The interviews were to be recorded and transcribed. As a part of the course, the answers received were, together with a presentation of the companies and their project, presented and discussed in a subsequent seminar. As all questions seldom were satisfactorily answered or the answers did not seem complete in the context of the descriptions given by the firm and its projects supplementary information had to be collected by phone or email in many of the cases, usually through several contacts by email. This has led to that, in many of the cases, the students and/or we ourselves have been in contact with the project managers interviewed at least one time after the field interview. This permitted the collection of supplementary data and checking on the reliability of the answers given. This laborious work process makes us confident to claim that the data is of much higher quality, than would it had been if it had 
been collected through a postal survey, and this is also the reason we can state that the sample consists of 92 case studies.

Table 1. The Companies Studied and Their Origin

\begin{tabular}{|c|c|c|c|}
\hline Country & \multicolumn{2}{|c|}{ Cases } & Companies \\
\hline Spain & 8 & & NN, NN, NN, NN, NN, Reuters, Artecesoft, NN \\
\hline Italy & 6 & & NN, AEA, Sinfo Pragma, Resiban, NN, RiskMap \\
\hline France & 6 & 20 & NN, Cap Gemini Ernst \& Young, Moore-Paragon, NN, Siemens, IBM \\
\hline Germany & 6 & & Debis, NN, Hewlett Packard, NN, NN, Medio \\
\hline Austria & 3 & 9 & Alcatel, NN, Trans-flow \\
\hline Belgium & 4 & & NN, BSB, Synes, Ubizen \\
\hline Holland & 4 & 8 & NN, NN, X-Hive Corporation, NN \\
\hline U.K. & 2 & 2 & NN, Ivy Learning \\
\hline Finland & 5 & & NN, Anilinker Oy, Icon Media Labs, Globalics, Mica Solutions \\
\hline Norway & 2 & 7 & Objectware, Divineo \\
\hline Russia & 2 & & Speech Technology Center, Star SBP \\
\hline Lithuania & 1 & & Alna \\
\hline Slovenia & 1 & & Hermes Softlab \\
\hline Estonia & 2 & 6 & Index Net, Abobase System \\
\hline USA & 2 & & Hewlett Packard (2 cases) \\
\hline Canada & 4 & & Altersys, NN, NN, NN \\
\hline Australia & 2 & & NN, Ericsson Australia \\
\hline Peru & 1 & 9 & $\mathrm{NN}$ \\
\hline Sweden & 31 & 31 & $\begin{array}{l}\text { Nexus, NN, Intentia, Altcom, NN, NN, NN, MedVind IT, Citerus, Tofs, EQUA, } \\
\text { TietoEnator, Kost och Näringsdata, BroadVision, Marratech, NN, Bonanza, Upright } \\
\text { Engineering, NN, Emerson Energy System, Paradox Entertainment, Envox Group, NN, } \\
\text { NN, Front Capital System, NN, Medvind IT, NN, Clinitrac, Svenska Market } \\
\text { Management Partners, ICL Invia }\end{array}$ \\
\hline Total & & 92 & \\
\hline
\end{tabular}

Note: When the respondent has not agreed on us mentioning the name of the firm the case is marked with NN. Large and well-known computer software firms are for some unknown reason(s) over-represented among those that did not want their company name to be revealed.

The data collected consisted not only of answers to fixed questions, but also of transcripts of taped comments on the fixed questions, answers to open ended questions, and written information about the companies and projects.

It is a very heterogeneous group of companies representing different sections of the computer software market, and companies of different age and size. When it comes to size the sample covers a wide range of software firms and projects. The average number of employees in the country of the study is 2,603 and 17,547 world-wide in the group. However, the median size of the local company in which the interview was made is only 50 employees; the lower quartile 11 and the upper 375 . The size of the projects varies less. The average size of the project is 232 man-months; median 60 man-months, lower quartile 13 and upper 200. The average number of people working on the project in-house is 14 ; median 8 . This means that most of the projects are not only more successful but also substantially larger, than the 
average computer software development project. In a survey answered by 162 Irish programmers Fitzgerald (1998) recorded an average project team size of 3.5 and a project duration of 3.7 months, i.e. a project size of work of less than 13 man-months.

These figures exclude the number of people in other organizations who have been involved in the projects, the work they have done and the work embedded in the software that was bought to be integrated in the new software program. Thus, the total number of people and work involved in implementing each of the projects is substantially higher, and dependent on how much of the total work that has been acquired from external sources. We have a measure also of this taken at the firm level saying that those interviewed estimated that 27 percent of the work had been acquired from external sources; median 20 percent, lower quartile 10 and higher 90 . However, we think many of the interviewees must have grossly underestimated the work done by external linkages, and thus we think the real composite figure must be substantially higher.

The research design has some obvious limitations. The sample is not randomised. It is biased towards large and successful software development projects. It is a heterogeneous sample including many different types of software, which, however, is an advantage as there is little previous research on the use of external linkages in software development projects and the aim is to explore this relatively unexplored area of research. The firms also come from different countries, however, the analysis shows no significant differences between e.g. Swedish and non-Swedish companies. Most of the interviews were made by last year students, who, however, had time to prepare themselves for this task through the abovementioned course. In spite of these limitations we think the sample can yield some reliable insights as the data is of high quality.

\section{A Model for the Analysis of External Knowledge Acquisition}

Hauschildt (1992:105) has developed a model of the various linkages involved in innovation termed "The informational relations of the innovating firm". The relations are divided into four groups: Markets; Scientific System; Government/Public Authorities; and Mediating System. Each one of these systems are either a sender or recipient of information, and anyone can initiate or terminate an informational relation. The relations are asymmetrical in the sense that initially the sender has a qualitatively higher level of knowledge than the recipient, an asymmetry which through prolonged interaction will decrease regardless if the partners develop new knowledge in cooperation or not.

Hauschildt (1992:105) points out that "[i]nnovations are processes which cover all stages from the discovery and development of a new product or technique up to its diffusion", but does not supply a model to study these stages. For this purpose a simple linear four stages model of product innovation was chosen consisting of an idea phase, a decision phase, a development phase, and a commercialisation phase. See Tables 6, 8 or 11 in which this model is used to summarize the relative importance of the different types of linkages studied.

The respondents had first been asked to choose a recent software development project, and give a general description of the project. They were then asked to identify external sources of knowledge used in the project, and to assess the relative importance of these linkages over the four stages of the project on a five-point Likert scale. Furthermore, they were asked to 
describe the type of the relationship the linkage implied, and to estimate for how long they had had this contact.

The model had been tested in the four companies interviewed in the pre-study. The respondents in these and the other 92 cases had no problems discussing the importance of their partners in this four stages model, even if software development processes are far from this simple. Traditional theory of innovation holds that innovations go through a linear sequence of phases (Klein and Rosenberg, 1986), but in practice it may contain loops and interactions between the phases. There are many software development processes in use, such as the waterfall model, the spiral model, the Rational Unified Process model, but these models were not strictly followed in many of the projects studied. Software development still has a character of craft technique and an ad hoc hacker mentality. However, as the four stages model proved to work well as an instrument to discuss the importance of external sources, this was chosen, together with a few less important modifications of the sources listed in Hauschildt's model. Also the five-point Likert scale, and the stepwise approach described above were retained in the main study.

In another set of questions we assessed the amount of knowledge that has been generated through the project. Knowledge was measured with regard to knowledge on the productionside, market-side, and administrative side. On the product-side we also distinguished between general-purpose knowledge and context-specific knowledge, which was a division earlier used by Torrisi (1998: 131) in his interview-based study of 51 European software firms. General-purpose (or generic) knowledge "draw[s] on scientific, abstract science", and context-specific knowledge (or application-specific) is "linked to experience and knowledge of specific users' needs and applications".

The respondents were asked to first state the company's level of knowledge prior to the software development project in question, then relative to where the company stands today, on a five-point Likert scale. The difference between the estimates is a measure of the knowledge generated due to the project. The assessment then provided a basis for discussing what each company had done to effect the changes in knowledge that had occurred. The same methodology has earlier been used by Segelod (1995). Notice also that the amount of knowledge generated is one of the most wildly used measures of relatedness in research on diversification and diversification strategies.

\section{Differences between Hardware and Software Development}

The high existence and use of external linkages in software development projects observed in this study can, at least partly, be explained by the very nature of software development projects. When designing and building a new bridge, aircraft, computer, or pharmaceutical drug, the engineers or scientists can take their point of departure in some requirements that their product has to meet and use these requirements to assess their achievements. Such firm point-of-departures seldom exist for software development engineers (Baetjer, H., 1998; Cugola and Ghezzi, 1998; Sheremata, 2002).

In most cases, the customer can not exactly specify what they need and want the software to be able to do. They have a perception of the problem that they want the software to solve for them, but they cannot translate this into precise requirements. The developer therefore has to start-out with informal, very imprecise and fuzzy requirements which typically will not only 
be made clear during the develop process but also can change and have to be changed as more is learned about the requirements and what is technically possible and economically feasible.

The software development process must therefore be not only open-ended, but also transparent. Feedback from the customers becomes important not only in the idea phase but also in the design, development, and commercialisation phases to align the end product to customer needs and wants as these are made explicit. The software development process, therefore, must be transparent; designed to allow visibility of what is being developed and to allow communication between customer and developer, so that the developer continuously can receive feedback from the customers. In this way a software development project has more in common with a customer-driven R\&D-project, than a tangible product development project. Furthermore, as project management can not, in detail, foresee the problems the programmers will have as problem solving is to a larger extent decentralized, than in tangible product development projects where there exist a body of theory that make it possible to estimate for instance the forces a bridge or an airplane will be exposed to. Software engineering does not have, or has not yet developed, standardised procedures of the type found in mechanical an aeronautical engineering.

These differences have, as we will show, consequences for the existence and use of external sources of knowledge in the development process. One could also suspect that these differences delimit the ability of the linear model of product development used in this study to describe what is actually going on in a software development project. However, some companies do, in fact, use a linear model called the waterfall model in which the project is supposed to proceed from one step to another; from feasibility study to requirements, to design, to implementation, and to system test. In our sample this simple software development model was used in 14 of the 92 project, i.e. in 15.2 percent of the cases. See Table 2. In four of cases no model was used at all, or a so called hacker approach, and in 36 of the cases they mixed ingredients from several different models.

Table 2. The Use of Formalized System Development Methodologies

\begin{tabular}{|l|c|}
\hline \multicolumn{1}{|c|}{ Methodologies } & User frequency \\
\hline No model or a hacker approach & $4.3 \%$ \\
\hline The waterfall model & $15.2 \%$ \\
\hline More advanced models & $31.6 \%$ \\
\hline Proprietary and custom models & $9.8 \%$ \\
\hline Mixed models & $39.1 \%$ \\
\hline
\end{tabular}

In Fitzgerald's (1998) survey 60 percent of the organizations researched did not use any 'formalized systems development methodology' at all. Fourteen percent used a commercial methodology, 14 percent an internal model, and 12 percent an internal model based on a commercial model. The lower use of formal systems development methodologies in Fitzgerald's sample can perhaps be explained by the fact that the average size of his projects was smaller; less than 13 man-months as compared to 232 man-months for our sample. As Fitzgerald addressed programmers and not projects it is reasonable to assume that his figures are much closer to the average software project, i.e. our software projects are on average comparably large projects.

One can wonder why companies prefer such a simple model as the waterfall model when there are much more realistic models allowing for continuous looping between the phases and for the creation of sequential prototypes. One answer to this question is that such models 
cannot be strictly followed. The model has to allow for improvisation to function properly; a certain 'hacker' freedom is necessary in software development. Moreover, the greater use of mixed models and proprietary and custom models indicate that firms are not satisfied with the standard models that exist. One explanation advanced by Fitzgerald is that these system development methodologies were evolved in the 1970's for the type of in-house single client projects that were the most common in those days. They were not developed for the types of projects that we see today, where software is developed in cooperation with external partners and parts of it are bought, modified, and put to new use. Another, but related, explanation is that computer software projects are so different that the methodology often has to be tailored to the specific software project. However, as earlier stated, the four stages model, a model resembling the waterfall model, was retained as it was simple and proved to work well in the pilot studies as an instrument to discuss the importance of external relations and sources of knowledge.

\section{The Number and Type of Relationships}

In all 718 linkages and sources of external knowledge were identified in the 92 computer software projects. This means an average of 7.80 linkages per case. In 392 of these cases (718-326) the respondents specified the actors and means, i.e. the type of relation that the linkage implied, that were involved. See Table 3.

Studying the last column in Table 3 we can conclude that the markets and mediating parties dominate, and that linkages to customers are the most important linkage. Focusing on the linkages that are specified, we can see that there are relatively few acquisitions of companies (A) and joint-ventures (B). Similarly there are relatively few cases were key managers (F) and other employees $(\mathrm{G})$ have been recruited to implement a specific software project. One explanation to this can be that such grafting forms of external knowledge acquisition are seldom used to facilitate the implementation of individual software projects. Learning through grafting is perhaps more often used to develop software companies, than to conduct software projects. Thus, software managers mostly have to rely on existing, including linked and previously known, resources.

Studying the last column in Table 3 we can conclude that the markets and mediating parties dominate, and that linkages to customers are the most important linkage. Focusing on the linkages that are specified, we can see that there are relatively few acquisitions of companies (A) and joint-ventures (B). Similarly there are relatively few cases were key managers (F) and other employees $(\mathrm{G})$ have been recruited to implement a specific software project. One explanation to this can be that such grafting forms of external knowledge acquisition are seldom used to facilitate the implementation of individual software projects. Learning through grafting is perhaps more often used to develop software companies, than to conduct software projects. Thus, software managers mostly have to rely on existing, including linked and previously known, resources.

Moreover, decisions to acquire companies, to form joint-ventures, and recruit key managers are decisions that need top management approval. The acquisition of companies and entering of joint-ventures usually need to be approved by the corporate board. Thus, if we had interviewed CEO's instead of project managers the figures might have been higher for these grafting types of means, which also means that top management would need to get more involved in the software projects. Studies of large-scale ventures in new areas based on 
interviews with senior managers (Segelod, 1995; 2001), show that learning through grafting can be a very important means of developing new knowledge in such new venture processes.

Table 3. Actors and Means Used to Acquire External Knowledge

\begin{tabular}{|c|c|c|c|c|c|c|c|c|c|c|}
\hline Actors / Means & $A$ & $B$ & $C$ & $D$ & E & $F$ & $G$ & $H$ & $I$ & Total \\
\hline \multicolumn{11}{|l|}{ Markets: } \\
\hline Customers & & 3 & 68 & 6 & 3 & 2 & 2 & 5 & 15 & 104 \\
\hline Suppliers & 1 & 2 & 18 & 15 & 1 & 1 & 1 & 8 & 19 & 66 \\
\hline Hardware manufacturers & & 3 & 18 & 7 & 1 & & 1 & 4 & 22 & 56 \\
\hline Competitors & 1 & & 16 & 1 & 1 & 2 & 3 & & 46 & 70 \\
\hline Affiliated companies & 5 & 6 & 16 & 1 & & & 1 & 8 & 15 & 52 \\
\hline Other sources & & & 5 & & & & 1 & 1 & 9 & 364 \\
\hline \multicolumn{11}{|l|}{ Scientific system: } \\
\hline Universities & & & 5 & & & & 5 & 5 & 16 & 31 \\
\hline Other research institutes & & & 8 & 1 & & & & 4 & 14 & 27 \\
\hline Other sources & & 1 & 2 & 1 & & & & 1 & 9 & 14 \\
\hline \multicolumn{11}{|l|}{ Public authorities: } \\
\hline Patent offices & & & 4 & & 3 & 1 & & 1 & 22 & 31 \\
\hline Financial promoters & & 1 & 4 & & & & & 2 & 17 & 24 \\
\hline Other sources & & & 3 & & & & & & 7 & 10 \\
\hline \multicolumn{11}{|l|}{ Mediating party: } \\
\hline Market consultants & & & 7 & & 1 & 1 & 5 & 20 & 15 & 49 \\
\hline Technical consultants & & & 7 & & & & 5 & 28 & 14 & 54 \\
\hline Business incubator & & & 1 & & & & & & 8 & 9 \\
\hline Press & & & 9 & & 1 & 1 & 1 & 1 & 34 & 47 \\
\hline Fairs/conferences & & & 11 & & & & & 2 & 40 & 53 \\
\hline Other parties & & & & & & & & 1 & 4 & 217 \\
\hline & & & & & & & & & & \\
\hline Total & 7 & 16 & 202 & 32 & 11 & 8 & 25 & 91 & 326 & 718 \\
\hline
\end{tabular}

Note: A = Acquisitions of companies; B - Joint-ventures; C - Other looser forms of cooperation; D - Licensing; E - Acquisition of proprietary rights; F - Recruitment of key managers; G - Recruitment of other employees; H Recruitment of temporary employees; I - Type of relationship not specified.

Comparisons can be made with Håkansson $(1989 ; 1990)$. He studied linkages in product development in 123 companies with 20 to 500 employees in the middle of Sweden, i.e. firms of about the same size as most of the companies in our sample. As Håkansson's sample represented a cross-section of industry such a comparison would roughly represent tangible product development practice in the Swedish manufacturing industry in the mid 1980's, versus the computer software industry represented by multiple countries in the late 1990's.

Håkansson $(1989$; 1990) distinguishes between customer relations, supplier relations, and horizontal relations. The latter includes complementary producers, competitors, universities, etc. He found that his companies had, on average relations with 4.5 customers, 3.2 suppliers, and 2.4 horizontal units in their product development projects. Translating his figures to our frame of reference Håkansson's sample would on average have 4.4 relations as compared to 7.0 for our software projects, or 5.789 linkages if one only wants to count linkages considered to be important. Still, the difference between Håkansson's and our sample is most probably higher than these figures indicate as Håkansson studied companies and we studied projects. See Table 4.

Table 4. Number of Linkages

\begin{tabular}{|c|c|c|c|c|c|c|}
\hline Measure & Mean & Median & $\operatorname{Min}$ & $\operatorname{Max}$ & $Q 1$ & $Q 2$ \\
\hline A. The number of actor/source types linked to the project & 7.152 & 6 & 1 & 18 & 4 & 10 \\
\hline $\begin{array}{l}\text { B. The number of relationship types used for all } \\
\text { actors/sources in the project }\end{array}$ & 7.826 & 6.5 & 1 & 25 & 5 & 11 \\
\hline $\begin{array}{l}\text { C. The number of actor/source types linked to the project } \\
\text { that have a rating of } 3-5 \text { in importance }\end{array}$ & 5.826 & 5 & 0 & 15 & 3.25 & 8.75 \\
\hline $\begin{array}{l}\text { D. The number of linked phases for all actors/sources used } \\
\text { in the project that have a rating of 3-5 in importance }\end{array}$ & 10.793 & 9 & 0 & 42 & 6 & 14 \\
\hline
\end{tabular}


Table 4 shows statistics for the different types of sources used, i.e. the number of actor/sources listed in the first column of Table 3. Several measures have been used for this purpose. The first above measure is for the number of actor/source types that are linked to the projects. The second measure for the involvement of the actor/source types in each project was the number of relationship types used for all actors/sources in a given project. In some cases the number of actor/source types linked to a project differed from and the number of relations hips that were used. This occurred because one or more of the actor/source types had more than one type of relationship to the project. For example, a given actor/source could be related as both a joint venture partner and a source of temporary employees. So the number of relationships for this actor/source became 2 rather than one. A few cases even showed three relationships for a single actor/source. Thus the maximum number of linkages for the actor/sources is the total number of possible links, 18 as shown in the left-hand column of Table 3, while the maximum number of relationships was determined empirically to be 25 . Both of these maximum values are shown in Table 4 under the Max column.

A third measure was the number of actor/source types linked to the project that have a rating of 3-5 in importance. This measure of course has a smaller mean number of linkages, 5.789 compared to the mean of 7.000 for the first measure and also a smaller maximum was found. A fourth measure was the number of linked phases for all actors/sources used in a given project that have a rating of 3-5 in importance. Thus when a particular actor/source was used in all four phases (shown in Table 6) this measure became 4 rather than just one as was used for tallying up the number of linked actor/source types. Thus the maximum number of linkages for the actor/sources is the total number of possible links, 18 as shown in the lefthand column of Table 3, while the maximum number of linked phases was determined empirically to be 42 . Both of these maximum values are shown in Table 4 under the Max column.

Twenty-nine percent of Håkansson's companies had no linkages with their customers in their product development process, 26\% 1-4 linkages, and 36\% more than 9 linkages. When it came to suppliers and horizontal units $27 \%$ and $24 \%$ respectively had no linkages at all, and most of the rest 1-4 linkages in each category.

In our sample none of the 92 software projects for which data existed were carried out without the use of knowledge acquired through external sources. In other words, $100 \%$ of the projects were carried out in cooperation with one or several external partners, a remarkable high figure compared to earlier studies of knowledge acquisition in the tangible product manufacturing industry.

Comparisons can also be made with Beesley and Rothwell's (1987) study of 100 innovative UK SMEs, and with Parolini's (1990) study of 80 Italian mostly small high-tech firms. Beesley and Rothwell found that " $89 \%$ of the firms studied had a significant link in at least one of the following areas: contract-out $R \& D$; joint $R \& D$ ventures; marketing relationships; manufacturing relationships; links with educational establishments, other public sector bodies and research associations" (Rothwell and Dodgson, 1991: 128). Taking into account only links to other companies and excluding public sector links the figure dropped to $84.5 \%$; excluding all links but technical and market links the figure dropped to 69\%. Parolini found that $63.8 \%$ of his companies engaged in agreements with other companies. 
In a similar study of 82 US SME:s over $80 \%$ of the innovative firms in the sample had at least one important external link, and almost 50\% at least three such links (Chandra and MacPherson, 1994). In a later US survey study of 472 SME:s over 50\% of the SME:s in the most innovative industry group, scientific instruments, had "significant links to at least 3 different categories of external support, compared to $40 \%$ for electrical products firms, $25 \%$ for metal fabricators, and less than $10 \%$ for furniture producers. Second, there is a positive relationship between contact diversity and innovation performance." (MacPherson, 1967: 138)

The higher values of linkages that Beesley and Rothwell, Parolini, and MacPherson, received over Håkansson confirms the notion that linkages and the amount of external knowledge acquisition correlates with measures of innovativeness as e.g. R\&D spending (Håkansson, 1989), product radicality (Zahra and Bogner, 1999) or discontinuous technical change (Jones et al., 2000). Comparing these three studies with ours we have to note that they studied companies and we studied projects, which may have caused our figures to be lower. A good illustration of this in our sample is provided by two large well-known computer software firms that developed the software in question for internal use. There were no external linkages to the market, only linkages to hardware manufacturers. These firms have, no doubt, a very well developed network of relations with other companies in- and outside the industry, which they can put to use if they later on would like to market the software in question, but these linkages were not needed in the projects we studied.

Considering these differences between the studies it looks like Hagedoorn (1993) was right when he pointed out the computer software industry as a good example of an industry in which external linkages were especially important. It is a heterogeneous and dynamic industry in which the technologies are so many and diverse that very few firms have access to all the different technologies needed in-house to develop advanced software applications. Moreover, technology is developing fast and the development work is difficult to patent or protect. The relative lack of legal protection, and the fast technical development, makes it less interesting to invest in developing completely new products through large in-house research projects, like in e.g. the pharmaceutical industry, and more interesting to buy and integrate existing technologies and software programs. The consequence is that computer software companies form more linkages and use more external knowledge, than do most tangible product manufacturing companies, and one could probably also add, than do most other high-tech companies. To know who has a specific knowledge is no doubt of great importance in the software industry.

\section{The Length of Relationships}

As earlier mentioned, Håkansson distinguished between customer relations, supplier relations, and horizontal relations. The latter included complementary producers, competitors, universities, etc. The weighted average length of the relations he studied was 13 years for customer and supplier, and 8 for horizontal relations. The average length of relations studied in this study is significant shorter or 4.265 years and the length of the relations for customers 4.7 years, suppliers 4.9 years, and for horizontal relations 4.0 years. This figure is based on 418 linkages. See Table 5. As can be seen by the figures for the lower (Q1) and higher (Q2) quartile the average length of the relations studied varies considerably from case to case. In Håkansson's study about one third of the linkages had a duration of 4 years or shorter, one third 5-14 years, and one third 15 years or longer. In this sample 50\% of the relations are 
shorter than 4.3 years, $47 \% 4.3$ to 15 years of age and not more than $3 \%$ of the relations 15 years or longer. Håkansson's manufacturing firms seem to have favoured long-term relations more than did our computer software firms.

Table 5. Length of Relationships

\begin{tabular}{|c|c|c|c|c|c|}
\hline $\begin{array}{c}\text { Sources / length of relation in } \\
\text { years }\end{array}$ & Mean & Median & $Q 1$ & $Q^{2}$ & $\begin{array}{c}\text { Number of } \\
\text { observations }\end{array}$ \\
\hline \multicolumn{6}{|l|}{ Markets: } \\
\hline Customers & 4.7 & 3.8 & 1.5 & 5.8 & 84 \\
\hline Suppliers & 4.9 & 3.5 & 2.0 & 5.0 & 43 \\
\hline Hardware manufacturers & 5.7 & 2.3 & 1.0 & 5.8 & 32 \\
\hline Competitors & 4.5 & 4.0 & 2.0 & 6.6 & 30 \\
\hline Affiliated companies & 4.0 & 3.0 & 2.0 & 4.8 & 32 \\
\hline Other sources & 2.8 & 1.5 & 1.0 & 4.5 & 9 \\
\hline \multicolumn{6}{|l|}{ Scientific system: } \\
\hline Universities & 4.6 & 4.0 & 2.0 & 6.0 & 19 \\
\hline Other research institutes & 6.1 & 6.0 & 1.8 & 10.0 & 14 \\
\hline Other sources & 3.1 & 3.0 & 0.4 & 5.8 & 4 \\
\hline \multicolumn{6}{|l|}{ Public authorities: } \\
\hline Patent offices & 4.0 & 3.5 & 2.0 & 5.8 & 16 \\
\hline As financial promoters & 4.4 & 4.0 & 1.7 & 6.0 & 12 \\
\hline Other sources & 4.8 & 5.5 & 2.0 & 6.8 & 4 \\
\hline \multicolumn{6}{|l|}{ Mediating party: } \\
\hline Market consultants & 3.2 & 2.0 & 1.0 & 5.0 & 28 \\
\hline Technical consultants & 2.1 & 1.5 & 0.5 & 2.0 & 38 \\
\hline Business incubator & 1.8 & 2.0 & 0.5 & 3.0 & 3 \\
\hline Press & 4.1 & 3.5 & 1.8 & 5.0 & 25 \\
\hline Fairs/conferences & 4.7 & 3.3 & 1.9 & 5.8 & 22 \\
\hline Other parties & 0.7 & 0.7 & 0.3 & 1.0 & 3 \\
\hline Average length of relations & 4.265 years & & & & \\
\hline Total number of observations & & & & & 418 \\
\hline
\end{tabular}

Comparing our figures with those of Håkansson one has to remember however, that software companies in general are much younger, than manufacturing companies; founded during the last three decades either as an independent start-up or a company in a larger group. Studying the linkages case by case one can observe that most companies have one link which has existed ever since the company was founded, in many of the cases even before it was founded. If the company was started by university people they have retained this linkage with the university and considered that linkage to be important. It is the same if the company started as a management-by-out from Ericsson or ABB, or the first software project of the company was developed in cooperation with a specific customer, supplier, hardware manufacturer, or affiliated company. In this way many of the cases have made use of one linkage which has existed already when the company was founded. Other linkages have often been of a more short-term nature. Excluding these long-term relations the average value of the rest of the linkages would become substantially shorter.

Studying the figures, one can also notice that the average length is markedly shorter for technical consultants, than for market consultants and the other sources of external knowledge. It looks like technic al consultants are more often hired for the development phase of a specific project, while market consultants more often works with a company on several software projects.

\section{Type of Partners and their Relative Importance}

As mentioned above, software development process was divided into four phases: the idea, the decision to develop, the development, and the commercialisation phase. The respondents were asked which external actors had been involved during these four phases, and how they 
would rank the importance of these actors to the software development project on a five-point scale from 1 (not important) to 5 (very important). In this context it should be noted that the linkages identified in this study and their importance only relates to the success of a specific software project and not to the company as a whole as in most other studies. The answers received are summarized in Table 6.

Table 6. The Relative Importance of Difference Linkages over All Project Phases - Part I

\begin{tabular}{|c|c|c|c|c|c|c|c|c|c|c|c|c|c|c|c|c|c|c|c|c|c|c|c|c|c|c|}
\hline \multirow[t]{2}{*}{ Phases/Souces } & \multicolumn{5}{|c|}{ Idea phase } & \multicolumn{5}{|c|}{ Decision phase } & \multicolumn{5}{|c|}{ Development phase } & \multicolumn{5}{|c|}{$\begin{array}{c}\text { Commercialisation } \\
\text { phase }\end{array}$} & \multicolumn{5}{|c|}{ All four phases } & \multirow[t]{2}{*}{ Total } \\
\hline & 1 & 2 & 3 & 4 & 5 & 1 & 2 & 3 & 4 & 5 & 1 & 2 & 3 & 4 & 5 & 1 & 2 & 3 & 4 & 5 & 1 & 2 & 3 & 4 & 5 & \\
\hline Markets: & & & & & & & & & & & & & & & & & & & & & & & & & & \\
\hline Custo & 91 & 6 & 4 & 17 & 48 & \begin{tabular}{|l|}
17 \\
\end{tabular} & 4 & & 26 & 34 & 25 & \begin{tabular}{|l|}
11 \\
\end{tabular} & 18 & \begin{tabular}{|l|}
16 \\
\end{tabular} & 19 & 19 & 5 & 1 & 25 & 32 & 70 & 26 & 42 & 84 & 133 & \\
\hline & 6 & 9 & 11 & 3 & 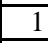 & 37 & 10 & 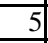 & 6 & 4 & 20 & 6 & 16 & 11 & S & 38 & 9 & 4 & 6 & t & 131 & 34 & 33 & 26 & 11 & J. \\
\hline Har & & 8 & & & 3 & 34 & 7 & 7 & 2 & & 2 & 5 & 23 & 5 & 4 & 29 & 3 & 8 & 4 & & 124 & 23 & 41 & 12 & 13 & \\
\hline Cor & 4 & 10 & 10 & 20 & 5 & 21 & \begin{tabular}{|l|l|}
13 \\
\end{tabular} & 8 & \begin{tabular}{|l|}
13 \\
\end{tabular} & 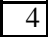 & 40 & , & 6 & $\overline{8}$ & 1 & 33 & 2 & 8 & 10 & & 108 & 28 & 32 & 54 & 13 & \\
\hline$\overline{\mathrm{Aff}}$ & 17 & 11 & 8 & $\overline{6}$ & 2 & \begin{tabular}{|l|}
19 \\
\end{tabular} & 8 & 8 & 5 & 5 & 17 & 6 & 8 & 10 & 4 & 16 & 3 & 9 & 13 & 8 & 69 & 28 & 33 & 34 & 15 & 79 \\
\hline Othe & 9 & $\overline{2}$ & 4 & 0 & 1 & 6 & 3 & 2 & 1 & 5 & 81 & 3 & 4 & 2 & 0 & 9 & 1 & 2 & 4 & 1 & 32 & 9 & 12 & & & 7 \\
\hline cient & & & & & & & & & & & & & & & & & & & & & & & & & & \\
\hline & 22 & 5 & 3 & . & 3 & 24 & 2 & 4 & 2 & 2 & 16 & 9 & 3 & 4 & t & 23 & 2 & 2 & 3 & 1 & 85 & \begin{tabular}{|c|} 
\\
$\mid 18$
\end{tabular} & 12 & 10 & 9 & 134 \\
\hline & 7 & 2 & 2 & 4 & 2 & 15 & 1 & 3 & 2 & 3 & 15 & 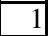 & 2 & 3 & 3 & 16 & 0 & 3 & 3 & 2 & 61 & $4 \mid$ & 10 & 12 & 10 & 97 \\
\hline & $\rightarrow$ & 1 & 1 & 2 & 0 & 8 & 1 & 0 & 2 & 0 & 7 & 7 & 0 & 2 & 0 & 8 & 1 & 0 & 2 & 0 & 31 & 51 & & 8 & 0 & $\overline{45}$ \\
\hline ubli & & & & & & & & & & & & & & & & & & & & & & & & & & \\
\hline$\overline{P_{i}}$ & 2 & 5 & 1 & 3 & 2 & 22 & 3 & 4 & 1 & 3 & 27 & & 2 & 2 & 0 & 15 & 3 & 6 & 3 & & 87 & 14 & 13 & 9 & & $\sqrt{32}$ \\
\hline $\bar{F}$ & 17 & 4 & & $\underline{0}$ & 7 & \begin{tabular}{|l|}
15 \\
\end{tabular} & 1 & 4 & 4 & 3 & 14 & & 0 & 2 & 5 & 14 & 4 & 1 & 1 & 21 & 60 & \begin{tabular}{|l|}
11 \\
\end{tabular} & 6 & 4 & 11 & 92 \\
\hline $\mathrm{O}$ & 6 & 2 & 0 & 3 & 0 & 6 & 2 & 2 & 0 & 1 & 8 & 3 & 0 & 0 & 0 & 7 & 2 & 0 & 2 & 0 & 27 & 9 & & 5 & 1 & 44 \\
\hline & & & & & & & & & & & & & & & & & & & & & & & & & & \\
\hline & 22 & 2 & 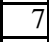 & & 4 & 22 & 3 & & 1 & 3 & 26 & & 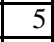 & & & 17 & 6 & 1 & 6 & of & 87 & 18 & 26 & 23 & 14 & $\underline{0}$ \\
\hline & 29 & & $\varepsilon$ & & 2 & 31 & 4 & & 5 & 5 & 12 & & 13 & & 12 & 36 & 4 & 7 & 2 & 2 & 108 & 17 & 29 & 22 & 21 & 9 \\
\hline B & & 0 & 3 & & 0 & 5 & 1 & 2 & 1 & 0 & 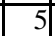 & 2 & 1 & 1 & 0 & 5 & 1 & 2 & 1 & & 20 & 4 & & 4 & 3 & \\
\hline$\overline{\mathrm{P}}$ & 33 & 7 & 3 & 2 & 1 & 39 & 4 & 5 & 0 & 0 & 32 & 5 & 9 & 1 & $\overline{0}$ & 9 & 2 & 14 & 12 & 11 & 113 & 18 & 33 & 15 & 12 & 19 \\
\hline irs & 27 & 5 & 6 & 8 & 7 & 36 & 7 & 4 & 5 & 1 & 30 & 9 & 7 & 6 & 0 & 10 & 6 & 13 & 18 & 6 & 103 & 27 & 30 & 37 & 14 & 211 \\
\hline Other parties & 6 & 0 & 0 & 0 & 0 & 7 & 0 & 0 & 0 & 0 & 6 & 0 & 0 & 0 & j & 7 & 0 & 0 & 0 & 1 & 26 & 0 & 0 & 0 & 2 & 2 \\
\hline tal & & & & & & & & & & & & & & & & & & & & & 342 & 293 & 363 & 366 & & \\
\hline
\end{tabular}

Note: The figures in each cell show the number of respondents ranking a linkage as 1 (not important), 2, 3, 4, and 5 (very important).

The table is based on 92 cases. The figures in each cell show the number of respondents ranking a linkage as 1 (not important), 2, 3, 4, and 5 (very important). For instance, in the first series of cells in the idea phase customers were considered as not important in 9 and very important in 48 of 92 cases.

In all 2,662 observations were recorded whereof about $50 \%$ or 1,342 observations were considered as existing, but not important, at least not in all four phases of the project. The remaining 1,320 observations, i.e. those linkages that were of at least some importance, were distributed roughly equally on $2,3,4$, and 5 . From this we can conclude that at least $50 \%$ of all linkages utilized in the average software development project are of no real importance to a successful project. The real figure of unimportant linkages could be even higher as one can assume that many of the respondents have disregarded or not remembered linkages of no real importance. We could term these unutilised or forgotten linkages latent linkages. They exist but were not utilized, and there are probably many such latent linkages which the interviewees did not recollect.

In Table 7 we can see that the percentage of unimportant linkages is distinctively lower for customer relations, than for the other types of linkages researched. Only $19.72 \%$ of the respondents considered their linkages to customers as unimportant in any one of the four phases, as compared to $50.54 \%$ for the average linkage. Still this is probably an underestimation of the importance of customer linkages as it could be assumed that less 
important linkages are underestimated. Linkages with the scientific system and public authorities, on the other hand, are amazingly often of low importance.

Table 7. The Relative Importance of Difference Linkages over All Project Phases - Part II

\begin{tabular}{|c|c|c|c|c|c|c|c|}
\hline Phases/Souces & 1 & 2 & 3 & 4 & 5 & $4+5$ & Observations \\
\hline \multicolumn{8}{|l|}{ Markets: } \\
\hline Customers & $19.72 \%$ & $7.32 \%$ & $11.83 \%$ & $23.66 \%$ & $37.46 \%$ & $61.13 \%$ & 355 \\
\hline Suppliers & 55.74 & 14.48 & 14.04 & 11.06 & 4.68 & 15.74 & 235 \\
\hline Hardware manufacturers & 58.22 & 10.80 & 19.25 & 5.63 & 6.10 & 11.73 & 213 \\
\hline Competitors & 45.96 & 11.91 & 13.62 & 22.98 & 5.53 & 28.51 & 235 \\
\hline Affiliated companies & 38.55 & 15.64 & 18.44 & 18.99 & 8.38 & 27.37 & 179 \\
\hline Other sources & 47.76 & 13.43 & 17.91 & 10.45 & 10.45 & 20.90 & 67 \\
\hline \multicolumn{8}{|l|}{ Scientific system: } \\
\hline Universities & 63.43 & 13.43 & 8.96 & 7.46 & 6.72 & 14.18 & 134 \\
\hline Other research institutes & 62.89 & 4.12 & 10.31 & 12.37 & 10.31 & 22.68 & 97 \\
\hline Other sources & 68.89 & 11.11 & 2.22 & 17.78 & 0.00 & 17.78 & 45 \\
\hline \multicolumn{8}{|l|}{ Public authorities: } \\
\hline Patent offices & 65.91 & 10.61 & 9.85 & 6.82 & 6.82 & 13.64 & 132 \\
\hline Financial promoters & 65.22 & 11.96 & 6.52 & 4.35 & 11.96 & 22.68 & 92 \\
\hline Other sources & 61.36 & 20.45 & 4.44 & 11.11 & 2.27 & 13.64 & 44 \\
\hline \multicolumn{8}{|l|}{ Mediating parties: } \\
\hline Market consultants & 51.79 & 10.71 & 15.48 & 13.69 & 8.33 & 22.02 & 168 \\
\hline Technical consultants & 54.82 & 8.63 & 14.72 & 11.17 & 10.66 & 21.83 & 197 \\
\hline Business incubators & 51.28 & 10.26 & 20.51 & 10.26 & 7.69 & 17.95 & 39 \\
\hline Press & 59.16 & 9.42 & 17.28 & 7.85 & 6.28 & 14.14 & 191 \\
\hline Fairs/conferences & 48.82 & 12.80 & 14.22 & 17.54 & 6.64 & 24.17 & 211 \\
\hline Other parties & 92.85 & 0.00 & 0.00 & 0.00 & 7.14 & 7.14 & 28 \\
\hline Average importance in $\%$ & 50.41 & 11.01 & 13.64 & 13.75 & 11.19 & $(24.94)$ & \\
\hline Total number of observations & 1,342 & 293 & 363 & 366 & 298 & $(664)$ & 2,662 \\
\hline
\end{tabular}

Note: The figures in each cell shows the percentage of total observations assigned an importance of 1, 2, 3, 4, and 5 respectively where 1 stands for 'not important' and 5 for 'very important'.

It is interesting to see that most linkages are formed with markets and mediating parties. Linkages to the scientific system and public authorities are less frequent. The most important linkage is not surprisingly customers. In 90 of the 92 cases customers have been involved in the project in at least one of the four phases. The remaining two software projects were developed by large software companies for internal use. For those the market existed inside the companies.

To analyse the importance of the various linkages in different phases of the projects Table 8 has been developed. The first figure for each phase shows the percentage of cases in which a linkage existed; the second figure the percentage of cases in which a linkage assigned an importance of 2-5 existed, and the last third figure the percentage of cases in which a linkage assigned an importance of 4-5 existed. The cell for the idea phase of customers, for instance, shows that there has been a linkage to customers in $96.7 \%$ of the 92 cases, that this linkage were of some value in $87.0 \%$, and of greater importance in $70.7 \%$ of the cases. The linkages that have existed in more than $50 \%$ of the cases have been marked in bold.

Moreover, considering the total number of observations, $50 \%$ of all observations equals $23.425 \%$ of all the linkages assigned an importance of $2-5$, and $15.139 \%$ of all linkages assigned an importance of 45 . Using this arithmetic bold has been used to show when a linkage has been given an importance of $2-5$ in more than $23.425 \%$ of the cases, and $4-5$ in $15.139 \%$ respectively.

We have seen that roughly 50 percent of the linkages utilized are ranked as unimportant in some of the phases of the project. As the number of linkages considered unimportant is very high, and as one can also assume that there exist a number of latent linkages, it becomes more 
interesting to focus on those linkages that have been of importance to the projects studied. Focusing on those figures high enough to be marked in bold one can observe that the linkages to markets and mediating parties are the most important. Taken source-by-source customer linkages are overall the most important linkages in all four phases. None of the other sources were close to the importance assigned to external linkages with customers. Suppliers and hardware manufacturer are of some importance in the development phase. This is contrary to competitors which are of greater importance in the early idea and decision phases. Affiliated companies tend to be of greater importance in the development and commercialisation phases, which can be explained in that the group as such consists of companies which in some of the cases have assisted in developing or marketed the software. The importance of linkages to universities is amazingly low, and not higher than those of other research institutes or patent offices. Market linkages are not surprisingly most important in the commercialisation phase and technical consultants in the development phase. More surprising has been the importance of linkages to the press, fairs and conferences not only in the commercialisation phase, but also in the idea and development phases. Obviously, information gained from the press, fairs and conferences, is often important when surveying possibilities and setting requirements for software projects.

Table 8. The Relative Importance of Different Types of Linkages in Different Phases

\begin{tabular}{|c|c|c|c|c|c|c|c|c|c|c|c|c|}
\hline \multirow[t]{2}{*}{ Phases/Sources } & \multicolumn{3}{|c|}{ Ideaphase } & \multicolumn{3}{|c|}{ Decision phase } & \multicolumn{3}{|c|}{ Development phase } & \multicolumn{3}{|c|}{ Commercialisation phase } \\
\hline & $1-5$ & $2-5$ & $4-5$ & $1-5$ & $2-5$ & $4-5$ & $1-5$ & $2-5$ & $4-5$ & $1-5$ & $2-5$ & $4-5$ \\
\hline \multicolumn{13}{|l|}{ Markets: } \\
\hline Customers & 96.7 & 87.0 & 70.7 & 96.8 & 78.3 & 65.2 & 96.8 & 69.6 & 38.0 & 95.6 & 75.0 & 62.0 \\
\hline Suppliers & 65.2 & $\begin{array}{llll}26.1 & & \\
\end{array}$ & 4.3 & 64.2 & 23.9 & 7.6 & 65.2 & 43.5 & 19.5 & 64.2 & 22.8 & 8.7 \\
\hline Hardware manufacturers & 55.5 & 17.4 & 4.3 & 55.5 & 18.5 & 3.3 & 56.5 & 40.2 & 9.8 & 53.2 & 21.7 & 9.8 \\
\hline Competitors & 64.1 & 48.9 & 27.2 & 64.2 & 41.3 & 17.4 & 63.0 & 19.6 & 9.8 & 60.9 & 25.0 & 14.1 \\
\hline Affiliated companies & 47.8 & 29.3 & 8.7 & 47.8 & 28.3 & 10.8 & 47.8 & 30.4 & 15.2 & 48.9 & 31.5 & 18.5 \\
\hline Other sources & 17.4 & 7.6 & 1.1 & 18.5 & 12.0 & 6.5 & 18.5 & 9.8 & 2.1 & 18.5 & 8.7 & 3.3 \\
\hline \multicolumn{13}{|l|}{ Scientific system: } \\
\hline Universities & 37.0 & 14.1 & 4.3 & 37.0 & 10.9 & 4.3 & 37.0 & 20.7 & 7.6 & 33.7 & 6.5 & 4.3 \\
\hline Other research institutes & 27.2 & 10.9 & 6.5 & 27.2 & 9.8 & 5.4 & 26.1 & 9.8 & 6.5 & 25.0 & 7.6 & 4.3 \\
\hline Other sources & 13.1 & 7.6 & 2.1 & 13.1 & 3.3 & 2.1 & 13.1 & 4.3 & 2.1 & 12.0 & 2.1 & 2.1 \\
\hline \multicolumn{13}{|l|}{ Public authorities: } \\
\hline Patent offices & 37.0 & 12.0 & 5.4 & 35.9 & 12.0 & 4.4 & 37.0 & 7.6 & 2.1 & 33.7 & 21.7 & 7.6 \\
\hline Financial promoters & 24.9 & 6.5 & 1.1 & 26.2 & 9.8 & 4.4 & 25.0 & 9.8 & 7.6 & 25.0 & 8.7 & 3.3 \\
\hline Other sources & 12.0 & 5.4 & 3.3 & 12.0 & 5.4 & 1.1 & 12.0 & 3.3 & 0.0 & 12.0 & 4.3 & 2.1 \\
\hline \multicolumn{13}{|l|}{ Mediating parties: } \\
\hline Market consultants & 45.8 & 21.7 & 12.0 & 45.8 & 21.7 & 10.8 & 45.8 & 17.4 & 4.3 & 45.8 & 27.2 & 13.1 \\
\hline Technical consultants & 53.2 & 21.7 & 9.8 & 54.4 & 20.7 & 10.8 & 55.5 & 42.4 & 21.7 & 51.1 & 12.0 & 4.3 \\
\hline Business incubators & 9.8 & 4.3 & 1.1 & 9.8 & 4.3 & 1.1 & 9.8 & 4.3 & 1.1 & 10.8 & 5.4 & 2.1 \\
\hline Press & 52.2 & 16.3 & 3.3 & 52.2 & 9.8 & 0.0 & 51.1 & 16.2 & 1.1 & 52.2 & 42.2 & 25.0 \\
\hline Fairs/conferences & 57.6 & 28.3 & 16.3 & 57.6 & 18.5 & 6.5 & 56.5 & 23.9 & 6.5 & 57.6 & 46.7 & 26.1 \\
\hline Other parties & 6.5 & 0.0 & 0.0 & 6.5 & 0.0 & 0.0 & 7.6 & 1.1 & 1.1 & 8.7 & 1.1 & 1.1 \\
\hline
\end{tabular}

Note: The first column in each phase shows the percentage of cases in which a linkage existed. The second column the percentage of cases in which a linkage assigned an importance of 2-5 existed, and the third column the percentage of cases in which a linkage assigned an importance of 45 existed. Important linkages, i.e. when a linkage has existed in more than $50 \%$ of the cases, are marked in bold. Considering the total number of observations, $50 \%$ of all observations equals $23.425 \%$ of all the linkages assigned an importance of 2-5, and $15.139 \%$ of all linkages assigned an importance of 4-5.

For software development projects good linkages with markets (i.e. customers, suppliers, etc) and mediating parties are more important, than linkages with the scientific system and public authorities. The most important linkage is without comparison that with customers. Customers linkages were not only the most frequent type of relation, but also the one deemed most important. Of the linkages studied the importance of customer linkages were rated 4-5 in $61.13 \%$ of the cases, followed by competitors $28.51 \%$, affiliated companies $27.37 \%$, fairs and conferences $24.17 \%$, market consultants $22.02 \%$, technical consultants $21.83 \%$, suppliers $15.74 \%$, universities $14.18 \%$, the press $14.14 \%$, patent offices $13.64 \%$, and hardware 
manufacturer $11.73 \%$. This list disregards linkages of which less than 100 observations exist. See Table 7.

The figures show that linkages with the scientific system and public authorities are less important than mediating parties and markets, and especially customers to computer software firms. There are also reasons to suspect that company size matters. Håkansson (1989), Rothwell and Dogson (1991) and our sample are dominated by small and medium sized firms. In a similar, but not directly comparable, interview study of 23 UK and 15 Japanese mostly large firms Tidd and Trewhella (1997) found that the most important source of external technology was universities. In that study universities were important in $79 \%$ of the companies, followed by consortia $61 \%$, licensing $34 \%$, customer and suppliers $34 \%$, company acquisition $16 \%$, joint-ventures and alliances $13 \%$, and commercial research organizations $5 \%$.

Comparisons with Håkansson's $(1989 ; 1991)$ study, show that software firms, compared to manufacturing firms, more often use external knowledge when developing new products. In fact, almost no firm developed new software in solitude. Håkansson did not investigate all the sources of external knowledge surveyed in this study, but the data presented makes it likely that other linkages apart from customers and suppliers are of greater importance to software firms, than to manufacturing firms. Furthermore, we can conclude from our study that software firms more frequently form new relations for a specific project, and more often enter into relations between small and large firms. This is in line with statistical studies showing that technological linkages are highest in emerging, dynamic industries (Auster, 1992). Firms in fast developing high-tech industries more and more have to specialize in and integrate different technologies, and they therefore have to form external linkages to get access to new technologies (Granstrand et al., 1992), and the software industry is a very good example of such a fast developing industry (Hagedoorn, 1993).

Analyses of firm linkages (Håkansson, 1989; 1991; Rothwell and Dogson, 1991; Woolgar et al., 1998) have shown that customers and suppliers are the two most important types of linkages innovative firms have. When it comes to software firms, customer linkages are overall the most important type of linkage, which can be explained by the fact that software has to be developed in close cooperation with the users as product requirements can often not be specified at the outset. The observation that suppliers seem to be relatively less important in software development, than in other industries, can be explained by the fact that suppliers do not adjust their hardware or software to the new software for which it is going to be used. The hardware is taken for given and put together re-using older parts of software, in close cooperation with the users. This makes customer linkages more, and supplier linkages less important, than in most other industries.

\section{Factors that Drive the Formation and Use of External Linkages}

We have developed four measures of the number of linkages to measure the importance of external linkages:

A. The number of actor/source types liked to the project

B. The number of relationship types used for all actors/sources in the project

C. The number of actor/source types liked to the project that have a rating of 3-5 in importance 
D. The number of linked phases for all actors/sources used in the project that have a rating of 3-5 in importance

The average number of linkages for each one of these four definitions have earlier been shown in Table 4. We will use these measures as dependent variable in a series of regression equations to model the factors that drive firms to form linkages and use external sources of knowledge. The measures give similar but slightly different values. As there are good arguments for all four measures, we have tested all four of these measures to find out which one is the most suitable to use.

We also have another, broader, measure of the amount of external knowledge, namely answers to the question: Generally speaking, how large a percentage of the new knowledge needed to complete the firm's software development projects has been acquired from external sources? However, as responses to this question were at the company level it might not apply to the specific project in question. Furthermore, this figure is low for some of the projects that according to the case descriptions have utilized many relations and acquired important knowledge from these relations. The average for the sample was $27 \%$; median $20 \%$, lower quartile $10 \%$ and higher $90 \%$. We therefore think that too many of the respondents have underestimated the amount of knowledge gained from external sources to make this a reliable measure. It looks like some of the respondents have omitted the tacit side of the knowledge that they have acquired. This shows how difficult it is to find good measures of the amount of knowledge acquired, and that the number of sources of external knowledge used might be a reasonably good proxy not only for the number of linkages used and their importance, but also for the amount of knowledge acquired from these sources.

External knowledge acquisition has attracted increasing attention in scientific journals during the last decade. There are several questionnaire-based studies of the phenomena. These deal with technology acquisition in SMEs in Norway (Sandven, 1996), in US computer software projects (Zahra and Bogner, 1999), US subsidiaries (Jones et al., 2000), and young technology-based firms (Yli-Renko et al., 2001). There are also studies that deal with the make-or-buy decision in a similar way such as Kurokawa's (1997) study of make-and-buy decisions in R\&D in small technology based firms in the US and Japan, and Veugelers and Cassiman's (1999) of make-and-buy decisions in Belgium manufacturing firms. Studying this and other literature we can identify the following factors that contribute to the use of external knowledge acquisition:

1. The profitability and success of the project

2. The innovativeness of the project

3. The amount of knowledge generated internally

4. The degree of intellectual capital protection

5. The absorptive capacity of the project

6. The size of the firm

7. The size of the project

8. The enhancement of firm reputation

9. The strengthening of external linkages

10. The enhancement of personnel knowledge

11. Company strategy

12. Industry specific conditions 
The profitability and success of the project. External knowledge acquisition has been found to be positively associated with the profit level and profit growth rate of the company (Zahra and Bogner, 1999). We have figures for many, but not all of the companies' revenue for the last three years as some of the companies are not publicly listed. However, the measure is also unreliable as we focus on projects and not companies, and, secondly, as several of the younger companies founded in the 1990s have not yet reached break-even. We will therefore substitute these measures with the following two measures of project profitability and success, and hypothesize that these measures are positively associated with external knowledge acquisition. Number of observations within parenthesis:

1a. Extent to which company profitability has been enhanced by this project (88)

1b. On what criteria were the success of the project judged? On a 1 to 5 scale what was the overall success? (88)

The innovativeness of the project. External knowledge acquisition has also been found to be positively associated with project specific characters like discontinuous technological change, project degree of radicality, innovativeness, low degree of technological relatedness to earlier projects (Rothwell and Dodgson, 1991; Kurokawa, 1997; MacPherson, 1997; Zahra and Bogner, 1999; Jones et al., 2000), and also with the complexity of the project that such innovativeness brings (Dogson, 1994). It is assumed that the more complex the product is the more input it requires from different sources. We have the following eight measures of innovativeness, which we hypothesize all will be positively associated with external knowledge acquisition:

2a. Potential for transfer of knowledge from this project to other subsequent internal projects (89)

2b. Product is a relatively new platform that departs substantially from prior products (84)

2c. Extent to which the feature set of this product differs from the closest prior development (80)

2d. Product performance compared to closest available competitive product for the market segment (86)

Overall estimated newness with respect to the closest prior product as seen by

2e. project team (87)

2f. company management (87)

2g. customers (86)

2h. competitors (79)

To average the importance of each one of these measures we have constructed an innovation index composed of answers to four different aspects of innovativeness all measured using a five-point Likert scale: Newness to the company; newness to the market; uniqueness of product benefits; and scope of innovativeness. Newness to the company is measured as both newness to project team, and company management. Newness to the market is based on both newness to the customers and competitors. Uniqueness of product benefits relates to both feature set difference over closest prior developed product, and product performance compared to closest available competitive product in the relevant market segment. Scope of innovativeness is based on both new product platform, and new modules for an existing product. We will start our computations by using this innovation index; later to evaluate the 
impact of the individual measures on which the index is based on the propensity to use external linkages. Our proposition is that the innovation index, as well as our other measures of innovativeness, are all positively associated with external knowledge acquisition.

\section{2i. Innovation index (92)}

The amount of knowledge generated internally. Relatedness can be measured in several different ways. One is to estimate the potential for transfer of knowledge from the old to the new product as in $2 \mathrm{a}$.- $2 \mathrm{~h}$. One of the most commonly used measure of relatedness in literature on diversification is, however, the amount of knowledge generated due to the project, i.e. knowledge when the project is completed minus knowledge prior to the project. Kazanjian and Drazin (1987: 347) write: "relatedness is directly proportional to the amount of knowledge to be generated during the process of diversification." Other using similar definitions are e.g. Teece (1980), Burgelman (1984), and Wernerfelt (1984). We use this way of estimating relatedness with regard to the following four different types of knowledge, and hypothesize that the amount of knowledge generated will be positively associated with our measure of external knowledge acquisition:

3a. General-purpose knowledge on the product-side (92)

3b. Context-specific knowledge on the product-side (92)

3c. Knowledge on the market-side (knowledge about market, marketing, and distribution/logistics) (87)

3d. Knowledge on the administrative side (knowledge about administrative personnel, financial, and juridical matters) (89)

The degree of intellectual capital protection. External knowledge acquisition has been found to correlate with the degree of intellectual capital protection (Kurokawa, 1997; Zahra and Bogner, 1999; Veugelers and Cassiman, 1999; Jones et al., 2000). We have one measure of intellectual capital protection and we will hypothesize that legal protection is negatively associated with external knowledge acquisition, that is, the weaker or less possible legal protection is the greater is the likelihood of external knowledge acquisition.

4. Extent to which the firm will likely be able to retain the knowledge gained as proprietary so that the creation of later products will be enhanced (90)

The absorptive capacity of the project. External knowledge acquisition is found to correlate with internally available resources or the absorptive capacity Cohen and Levinthal (1990) of the firm (Torrisi, 1998; Veugelers and Cassiman, 1999; Jones et al., 2000). Rothwell and Dodgson (1991: 135) found that "[o]ne of the prime stimuli to collaboration has been shown to be the employment of in-house QSE." Qualified Scientists and Engineers is thought to give SMEs the outward-looking absorptive capacity needed to identify external knowledge and cooperate with equals in larger firms, something that has been confirmed by, among others, Britton (1993) and MacPherson (1997). Cohen and Levintahl (1990) call this capability absorptive capacity and defines it as the

"ability of a firm to recognize the value of new, external information, assimilate it, and apply it to commercial ends" (Cohen and Levintahl, 1990: 569)

Cohen and Levintahl's definition involves both an inward-looking and an outward-looking component of absorptive capacity. The outward-looking component can be developed 
internally through learning by observation and by trial and error, or acquired by recruiting new employees with long experience of the area in question. The inward-looking component is the ability to assimilate external knowledge and apply it to commercial ends. Compare also Zahra and George (2002) who in their review of research on absorptive capacity separate between, on the one hand, the acquisition and assimilation, and, on the other hand, the transformation and exploitation of external knowledge. We will measure the outward-looking component of absorptive capacity as the amount of knowledge prior to the project was commenced with regard to

5a. general-purpose knowledge on the product-side (92)

5b. context-specific specific knowledge on the product-side (92)

5c. knowledge on the market-side (knowledge about market, marketing, and distribution/logistics) (87)

5d. knowledge on the administrative side (knowledge about administrative personnel, financial, and juridical matters) (89)

Compare 5a-5d with 3a-3d. We will measure absorptive capacity as the amount of knowledge prior to the project was started, and relatedness as the amount of knowledge generated during the project. The distinction between general-purpose and context-specific knowledge has been borrowed from Torrisi (1991) who proposed that general-purpose skills gives absorptive capacity while context-specific skills does not:

"Hypothesis 1. Firms that rely on generalpurpose skills, such as those in mathematics, for their innovative activities will be open towards a wide range of external sources of innovation, including sources of generic, codified knowledge, such as universities, and sources of more specific knowledge such as competitors.

Hypothesis 2. Firms relying on context-specific skills, such as the experience with particular applications, for their innovative activities will be less open towards external sources of innovation compared with firms relying on general-purpose skills. However, they will be more open towards context-specific sources of knowledge (for example, lead users)." (Torrisi, 1991: 143-144)

Torrisi's hypotheses were supported in a logit regression model on 34 of his sample of 51 firms. Based on Torrisi we will hypothesize that general-purpose knowledge has a positive effect on the absorptive capacity, while context-specific skills does not have such an effect. We will also hypothesize that prior knowledge on the market-side and administrative side will be positively associated with external knowledge acquisition. The idea here is that prior knowledge both about the market and administration will make it easier to identify suitable cooperative partners, form external linkages, and make good use of these relations.

The size of the company. One aspect often discussed in the literature is company size. It is assumed that small firms are more dependent on external knowledge, than are large ones as the latter have more knowledge in-house (Macdonald, 1995; Sandven, 1996; Torrisi, 1998; Veugelers and Cassiman, 1999). Moreover, Veugelers and Cassiman (1999) found that large firms are more likely to both develop new knowledge in-house, and buy new knowledge, while small firms are more likely to adopt an innovation strategy of either develop or buy. However, Torrisi (1998: 140) who did interviews in 51 European software firms found that "[f]irm size does not show any significant effect on the propensity to search for external sources of technological change". 
We have two measures of company size. Company size is measured as both total number of company employees on global basis, and number of employees in the country where the interviewee works. To account for connectivity within large firms we use the ratio between country employee size and total company size. We will hypothesize all these three measures are negatively associated with external knowledge acquisition.

6a. Total number of company employees on global basis? (92)

6b. Number of employees in the country where the interviewee works? (92)

6c. Ratio of country employee size $(\mathrm{cN})$ to total company size $(\mathrm{tN})$ (connectivity within large firm) as $6 \mathrm{~b} / 6 \mathrm{a}(92)$

However, we will not use any of these three measures in our regression analysis as company size is far from normally distributed. The sample is dominated by many small firms and tails off towards large firms. Also plotting our variables of size and linkages does not reveal any clear connection between size and the number of linkages. To analyse the importance of size more thoroughly one has to classify the sample into various size categories and analyse each size class, but this is outside the scope of this paper.

The size of the project. There are many studies of knowledge acquisition and company size, but to our knowledge none on the importance of project size. The reason can be that almost all studies of external knowledge acquisition rely on company data. The only reference found that focuses on knowledge acquisition in projects, as opposed to companies, is Zahra and Bogner (1999). They sent a mail questionnaire to 581 software new ventures and received 116 usable replies, or a response rate of $20.9 \%$. However, they treated company size as a control variable, and had no measure for the size of the project team. The reason we have included measures of project size is that we think it can be a measure of both absorptive capacity and complexity.

Project size is measured both as project team total number, and full-time equivalent manmonths used for project. To create a measure of the importance of the project we have calculate the ratio of project team size to number of country employees. The idea is that more linkages are needed when the project is large compared to the size of the company. The larger the company is relatively to the project the more of the knowledge needed could be expected to exist inside the company. We hypothesize that these three measures are all positively associated with external knowledge acquisition.

7a. Project team total number (92)

7b. Full-time equivalent man-months used for project (90)

7c. Ratio of project team size to number of country employees $(\mathrm{cN})$ as $7 \mathrm{a} / 6 \mathrm{~b}(92)$

None of these measures of size are normally distributed although not as far off from normal distribution as company size, especially for the first measure, project team total number. As regression analyses are quite robust against skewed distributions we will, however, include these variables in our computations.

We see project team size first of all as a measure of absorptive capacity. The larger the team is the larger the external interface that the team will have and the larger will be its ability to form and make use of external linkages. The number of man-months used for the project should not be equally important to the absorptive capacity of the project. 
Both measures of project size could also be expected to be a measure of the complexity of the project. The larger the team size and the more man-months needed to complete the project the more complex the project is likely to be. However, we expect absorptive capacity to be the more important aspect of at least project team size in explaining the propensity of project teams to form external relations. Moreover, the complexity of a software development project has more to do with all the different parts, including external linkages that have to be coordinated. Thus, the dependent variable, the number of linkages, grossly contributes to the complexity of a project.

The enhancement of firm reputation. We used the single word 'reputation' rather than the term 'corporate image' that has the same meaning. Many innovative firms have come to understand that the successful development of new products enhances corporate image or reputation among its stakeholders (Thomas, 1993). Similarly the credibility of the company and product can be enhanced by cooperating with well-known firms (Tidd and Trewhella, 1997). The business press of course helps this by publishing reports about cooperation agreements and performance-related topics that affect customer and stakeholder perceptions. The innovative companies also direct their own marketing programs in ways to build brand name equity for the proposition that they are a leading innovator (Ibid.). Building corporate image is a multi-year strategic objective that affects "how the company and its products are perceived by its customers" (Twiss, 1974: 122).

It has been reported that product newness/superiority is the leading factor related to new product success according to discriminant analysis and that this factor was found in $82 \%$ of successful new products (Cooper, 1979). Another study concluded with three rules for developing successful new products. One of these was to "be there first with a new idea" (Davidson, 1976: 120). So being first into the market with a superior product is clearly a way to enhance reputation or corporate image among the company's stakeholders. We will hypothesize that our measure of firm reputation will be positively associated with external knowledge acquisition.

\section{Extent to which firm reputation has likely been enhanced by this project (92)}

The strengthening of external linkages. Strengthening of linkages will facilitate more efficient cooperation and hence will aid knowledge acquisition in the future. It has been observed that multi-learning extends beyond the company itself to suppliers and vendors. The inter-working sets up a mutual dependence between suppliers and manufacturers that turns upon close cooperation and communication. Contact is frequent, sharing of personnel is common, and information flow is dense (Dussauge, et al, 1992). It was also pointed out that long-term linkages permit the innovating firms to leverage their technological assets. We will hypothesize that our measure of the strengthening of external linkages will be positively associated with external knowledge acquisition.

9. Extent to which this project strengthened linkages between your company and to the customer(s) will likely help your firm in the future (91)

The enhancement of personnel knowledge. Personnel knowledge enhancement was taken as a measure of the general learning that occurred during a given project. Organizational learning as a term goes back at least to Cyert and March (1963). A few years later Thompson argued that organizations have to be interdependent with other firms and individuals in the 
environment (1967). The internal and external sharing of knowledge that occurs then enhances the personnel knowledge base for future projects. This has been regarded as a positive effect flowing from a given project. Some companies already have internal programs in-place for enabling their personnel to maximize the intake of knowledge in assigned areas so personnel knowledge clearly a firm resource (den Hertog, et al, 1995; 2000). We will hypothesize that our measure of personnel knowledge enhancement will be positively associated with external knowledge acquisition.

10. Extent of personnel knowledge enhancement that occurred during this project for project team members (90)

Company strategy. External knowledge acquisition has also been claimed to be influenced by for instance company history (Kurokawa, 1997; Tidd and Trewhella, 1997). We do not have a measure of the companies' previous experience of external knowledge acquisition, but we have a number of measures of company knowledge management strategy, and we will hypothesize that $11 \mathrm{a}-\mathrm{c}$ and $11 \mathrm{e}$ will be positively, and $11 \mathrm{~d}$ negatively associated with external knowledge acquisition.

11a. We buy specialist knowledge (91)

11b. Instead of developing, we buy knowledge in areas where other companies are more advanced (91)

11c. We buy knowledge when the knowledge is easy to transfer from external sources (91)

11d. When new knowledge can be developed in-house this is usually favoured as I offers more control of the development process (91)

11e. New knowledge is not bought unless management is familiar with that specific type of knowledge (89)

These five measures have been chosen from a list of 23 measures of a company's knowledge strategy by the use of factor and correlation analysis to ensure that the measures represent different groups of measures and are not greatly intra-correlated with each other.

Industry specific conditions. External knowledge acquisition has been found to be positively associated with industry specific conditions like the heterogeneity of the market, industry dynamism, hostility, fast technical development, intensive product upgrade, market growth rate, and industry R\&D spending level (Link and Tassey, 1987; Auster, 1992; Hagedoorn, 1993; Kurokawa, 1997; Zahra and Bogner, 1999). External linkages have been found to be more frequent in emerging and dynamic industries (Auster, 1992) like the computer software industry (Hagedoorn, 1993). We do not have any good measure of differences in market conditions, so we will have to assume that market conditions are the same for the whole sample.

Our list of independent variables contains no less than 31 independent variables grouped in 10 categories. In addition, some of the variables within the groups are highly correlated. We will therefore start by testing all variables to see which ones can be excluded. To avoid inflating our $\mathrm{R}$ square values we will continue this process of reducing the number of independent variables to the point that only those variables remain that will enter the regression equation presented. Using this step-wise methodology we arrive at the regression equation in Table 10. 
Table 10. Determinants of the Number of Important Linkages in Software Projects

\begin{tabular}{|c|c|c|c|c|c|c|c|}
\hline Variables & \multicolumn{7}{|c|}{ Estimates } \\
\hline Step & 1 & 2 & 3 & 4 & 5 & 6 & 7 \\
\hline Constant & 11.223 & 9.978 & 9.483 & 8.904 & 7.608 & 6.851 & 7.217 \\
\hline \multirow[t]{2}{*}{ 4. Legal protection } & -1.31 & -1.56 & -1.63 & -1.59 & -1.59 & -1.49 & -1.63 \\
\hline & $(-3.43)$ & $(-4.17)$ & $(-4.52)$ & $(-4.45)$ & $(-4.50)$ & $(-4.16)$ & $(-4.47)$ \\
\hline \multirow[t]{2}{*}{ 2f. Newness to management } & & 0.70 & $\mathbf{0 . 7 3}$ & 0.74 & 0.71 & 0.66 & 0.72 \\
\hline & & $(2.72)$ & $(3.20)$ & $(3.27)$ & $(3.19)$ & $(2.95)$ & $(3.20)$ \\
\hline \multirow[t]{2}{*}{ Dummy for groups D-F } & & & 1.75 & 1.82 & 1.83 & 2.24 & 2.23 \\
\hline & & & $(2.72)$ & $(2.86)$ & $(2.92)$ & $(3.28)$ & $(3.30)$ \\
\hline \multirow[t]{2}{*}{ 7b. Number of man-months } & & & & 0.00131 & 0.00129 & 0.00141 & 0.00132 \\
\hline & & & & (1.91) & $(1.90)$ & $(2.07)$ & $(1.96)$ \\
\hline \multirow[t]{2}{*}{ 11a. Buy specialist knowledge } & & & & & 0.40 & 0.40 & 0.40 \\
\hline & & & & & $(1.64)$ & $(1.65)$ & $(1.96)$ \\
\hline \multirow[t]{2}{*}{ Dummy for group $\mathrm{G}$} & & & & & & 1.08 & 1.23 \\
\hline & & & & & & $(1.46)$ & $(1.67)$ \\
\hline \multirow[t]{2}{*}{ 7c. Ratio of $7 \mathrm{a} / 6 \mathrm{~b}$} & & & & & & & -0.60 \\
\hline & & & & & & & $(-1.59)$ \\
\hline Standard Error & 3.07 & 2.93 & 2.82 & 2.78 & 2.75 & 2.72 & 2.70 \\
\hline R Square & 12.79 & 21.34 & 28.15 & 31.39 & 33.74 & 35.57 & 37.71 \\
\hline Adjusted R Square & & & & & & & 29.0 \\
\hline Number of observations & 82 & 82 & 82 & 82 & 82 & 82 & 82 \\
\hline
\end{tabular}

Note: T-Ratios within brackets.

Note: Variables for which the direction hypothesized were supported in bold.

Note: T-ratios significant on a 95 percent level in bold.

Note: Dummy for group D-F, and G are dummy variables.

We had four alternative dependent variables A, B, C and D. Variables B and C tend to give slightly higher $\mathrm{R}$ square values. However, the differences are small and the order of the first few variables that enter the equation does not generally change. Furthermore, $\mathrm{C}$ has a better normal distribution, than its alternatives. We will therefore use dependent variable $\mathrm{C}$, the number of actor/source types liked to the project that have a rating of 3-5 in importance, in all regression equations shown in this paper.

Studying Table 10 the first observation we can make is the low $\mathrm{R}$ square that we received. It does not matter which of our four measures of the number of sources of external linkages that we use, the $\mathrm{R}$ square value remains on about the same level. The number of missing values is relatively low, only $10.87 \%$, and derives mainly from our measure of innovativeness; newness to management. However, even if the predictive power of the regression equation in Table 10 is low, the equation does not change much when unimportant variables are deleted and the coefficients have the direction that we predicted them to have.

We will in the next section split the sample up in three sub-samples: A-C, D-F and G. It is interesting to see that the dummy variables for the two of the groups, groups D-F and G, enters the equation. The high Tratios for the dummy variable for group D-F means that at least this group differs significantly from the sample as a whole with regard to the equation in Table 10.

There are four variables in the equation presented in Table 10 that are significant on the 95 percent level. The T-ratios of these variables are marked in bold in Table 10. The first one is the extent to which the firm will likely be able to retain the knowledge gained as proprietary 
so that the creation of later products will be enhanced. The number of important linkages increase, when legal protection is weak, i.e. weak legal protection contributes to the high degree of external relations in product development projects in the computer software industry.

The second is the overall newness of the product to company management with respect to the closest prior product. Replacing all our measures of newness/innovativeness with the innovation index, the innovation index will enter the equation on the sixth place. The newness of the new product to company management and the project team are the two variables most important to the number of important linkages in the innovation index. The more innovative the new product is, and especially the more new the product is to the management and project team, the more important will external linkages be to the software development project.

On the third place follows the number of man-months spent on the project. Excluding this factor the size of the project team will enter the equation, but this factor will not be significant. The last variable that is significant is a measure of the knowledge strategy of the company: We buy specia list knowledge.

\section{Customized Software versus Packaged Mass-Market Software}

It is customary to separate between, on the one hand, packaged mass-market software and, on the other hand, customized software or enterprise solutions. A packaged mass-market software is a standard package like Microsoft Windows which can be installed on a pc or other type of computer with little or no modification. A customized software is developed for a specific user, and an enterprise solution is a software like SAP's R/3, which has to be adapted and modified to the need of the user. When it comes to enterprise solutions in general it is estimated that 30 percent of the cost of implementing such a system derives from license fees and 70 percent from professional service to implement the product (Hoch et al., 2000: 36). Such an installation in a large corporation can take years to complete. To both develop software products and offer service to customize software is considered a difficult task to manage within one organization which is why the software service and customisation work often is out-sourced.

The two types of software firms face different competitive conditions. In the software product business it is important to gain market share since the marginal cost of producing still another copy of a program is almost zero. This drives the software product business towards higher concentrations and gives rise to the expression: 'The winner takes all.' In the professional service industry, on the other hand, the ability to re-use parts of software developed for earlier customer are very limited and the marginal cost is nearly constant. Customers are more local and the key profitability parameter is the firm's capacity utilization rate.

The market for packaged mass-market software is dominated by large U.S. firms. Most European firms are either niche players, produce customized software or implement standardized software (Torrisi, 1991; Mowery, 1996; Dutta et al., 1998). As our sample contains software of both categories it was of interest to see to what extent these differences between customized and mass-market software are reflected in the way external linkages and knowledge were used in the development process. Torrisi who did interviews in 51 European computer software companies indicated that such differences do exist: 
"There are some differences between firms specialised in software platforms (system software and development tools) and firms specialised in software solutions (application solutions, customised software and services). The former focus more on publications, fairs, meetings and universities as external sources of innovation, while the latter rely on lead users, the links with hardware manufacturers, and the acquisition of new personnel. The hiring of new personnel is particularly important for firms specialised in customised software and services. These differences show that there is a relationship between the nature of firms' competencies (measured by their product specialisation) and the type of channels firms choose to gain access to external knowledge." (Torrisi, 1991: 139-140)

One problem in testing these observations is that the distinction between customized and mass-market software is far from as clear cut as one might think. Software is constantly upgraded and modified to suit new customer segments. Sorting out the alternatives that there are we arrive at the following seven categories, whereof the sample contains examples of six of these categories:

Type A: Projects undertaken for a single client company at its request. No follow-on program reported. (10 of the 92 cases belongs to this category)

Type B: Project undertaken for a single client company at its request. Some follow-on programs created for other users connected to that client. (4 cases)

Type C: Project undertaken initially for single client company at its request. The software firm then discovers a mass market of other like users and produces more such programs. Customized versions are made or might be made for different users. The reported project was the original version for that first client. (17 cases)

Type D: Project undertaken initially for a single client company at its request. The software firm then discovers a mass market of other like users and produces more such programs. Customized versions are made for different users. Reported project was a version for the mass market. (7 cases)

Type E: Project undertaken initially for a single client company at its request. The software firm then discovers a mass market of other like users and produces more such programs. Customized versions are not made for different users. (0 cases)

Type F: A software firm initially discovers a mass market of and produces one or more versions under its own initiative. Reported project was a version for the mass market. Customized versions are made for different users. (30 cases)

Type G: A software firm initially discovers a mass market of and produces one or more versions under its own initiative. Reported project was a version for the mass market. Customized versions are apparently not being made for different users. (24 cases)

As there will be too few cases in some of the seven categories we will merge related categories into three roughly equally large groups:

1 - Single client pure customised projects (A-C; 31 cases)

2 - Mass market projects in need of later usage customisation of some form (D-F; 37 cases)

3 - Pure mass- market projects that do not need customisation (G; 24 cases)

In the first group we have single client software projects. Customized versions have been made for 17 of the 31 cases in this group, but the data relate to the first single client project. In 
the second group we have software projects intended for a mass-market; projects that either are a new version of a single client program or need customisation to be installed. And finally, in the last group, we have pure mass-market software which does not need customisation.

The relative importance of different linkages in different phases for these three groups of software projects is shown in Table 11. The three figures in each cell show the percentage of observations ranking the link in question as a 4 or 5 , i.e. as being of great importance. The first figure in each cell relates to type A-C (31 cases), the second to D and F (37 cases), and the third to $\mathrm{G}$ projects ( 24 cases). Figures higher than $15.139 \%$ in bold. Compare this table with Table 8, which showed the same figures for the sample as a whole.

Table 11. The Relative Importance of Different Types of Linkages in Different Phases for Software Package versus Customized Software

\begin{tabular}{|c|c|c|c|c|c|c|c|c|c|c|c|c|}
\hline \multirow[t]{2}{*}{ Phases/Sources } & \multicolumn{3}{|c|}{ Idea phase } & \multicolumn{3}{|c|}{ Decision phase } & \multicolumn{3}{|c|}{ Development phase } & \multicolumn{3}{|c|}{ Commercialisation phase } \\
\hline & $A-C$ & $D-F$ & $G$ & $A-C$ & $D-F$ & $G$ & $A-C$ & $D-F$ & $G$ & $A-C$ & $D-F$ & $G$ \\
\hline \multicolumn{13}{|l|}{ Markets: } \\
\hline Customers & 71.0 & 71.8 & 62.5 & 71.0 & 60.0 & 62.5 & 41.9 & 33.3 & 41.7 & 41.9 & 69.2 & 75.0 \\
\hline Suppliers & 3.2 & 7.7 & 0.0 & 9.7 & 7.7 & 4.2 & 16.1 & 20.5 & 8.3 & 3.2 & 7.7 & 12.5 \\
\hline Hardware manufacturers & 0.0 & 7.7 & 4.2 & 9.7 & 7.7 & 0.0 & 6.5 & 10.3 & 8.3 & 0.0 & 15.4 & 12.5 \\
\hline Competitors & 12.9 & 33.3 & 33.3 & 6.5 & 23.1 & 25.0 & 3.2 & 7.7 & 12.5 & 3.2 & 17.9 & 20.8 \\
\hline Affiliated companies & 0.0 & 10.3 & 16.7 & 6.5 & 5.1 & 25.0 & 12.9 & 10.6 & 25.0 & 3.2 & 20.5 & 33.3 \\
\hline Other sources & 0.0 & 2.6 & 0.0 & 0.0 & 5.1 & 16.7 & 0.0 & 0.0 & 8.3 & 0.0 & 0.0 & 20.8 \\
\hline \multicolumn{13}{|l|}{ Scientific system: } \\
\hline Universities & 3.2 & 2.6 & 8.3 & 0.0 & 5.1 & 12.5 & 0.0 & 7.7 & 16.7 & 3.2 & 2.6 & 8.3 \\
\hline Other research institutes & 3.2 & 5.1 & 12.5 & 0.0 & 2.6 & 16.7 & 0.0 & 7.7 & 12.5 & 3.2 & 5.1 & 4.2 \\
\hline Other sources & 3.2 & 2.6 & 0.0 & 3.2 & 2.6 & 0.0 & 3.2 & 2.6 & 0.0 & 0.0 & 5.1 & 0.0 \\
\hline \multicolumn{13}{|l|}{ Public authorities: } \\
\hline Patent offices & 3.2 & 7.7 & 0.0 & 0.0 & 7.7 & 4.2 & 0.0 & 2.6 & 4.2 & 6.5 & 5.1 & 4.2 \\
\hline Financial promoters & 0.0 & 0.0 & 4.2 & 0.0 & 7.7 & 8.3 & 3.2 & 7.7 & 12.5 & 0.0 & 5.1 & 4.2 \\
\hline Other sources & 3.2 & 2.6 & 4.2 & 0.0 & 0.0 & 4.2 & 0.0 & 0.0 & 4.2 & 3.2 & 2.6 & 4.2 \\
\hline \multicolumn{13}{|l|}{ Mediating parties: } \\
\hline Market consultants & 6.5 & 15.4 & 8.3 & 9.7 & 7.7 & 12.5 & 9.7 & 0.0 & 0.0 & 6.5 & 17.9 & 12.5 \\
\hline Technical consultants & 12.9 & 10.3 & 4.2 & 9.7 & 10.3 & 12.5 & 32.3 & 15.4 & 16.7 & 3.3 & 5.1 & 25.0 \\
\hline Business incubators & 0.0 & 2.6 & 0.0 & 0.0 & 2.6 & 0.0 & 0.0 & 2.6 & 0.0 & 3.2 & 2.6 & 0.0 \\
\hline Press & 0.0 & 7.7 & 0.0 & 0.0 & 0.0 & 0.0 & 0.0 & 0.0 & 0.0 & 6.5 & 35.9 & 29.2 \\
\hline Fairs/conferences & 6.5 & 20.5 & 20.8 & 3.2 & 10.3 & 4.2 & 3.2 & 10.6 & 4.2 & 6.5 & 33.3 & 37.5 \\
\hline Other parties & 0.0 & 0.0 & 0.0 & 0.0 & 0.0 & 0.0 & 0.0 & 2.6 & 0.0 & 0.0 & 2.6 & 0.0 \\
\hline
\end{tabular}

Note: The three figures in each phase show the percentage of observations ranking the link in question as a 4 or 5 , i.e. as being of great importance. The first figure in each phase relates to type A-C ( 31 cases), the second to D and $\mathrm{F}$ (39 cases), and the third to G projects ( 24 cases). Compare Table 8 which shows the same figures for the sample as a whole in the third column for each phase.

Note: Important linkages, i.e. when a linkage has existed in more than $50 \%$ of the cases, are marked in bold. Considering the total number of observations, $50 \%$ of all observations equals $15.139 \%$ of all linkages assigned an importance of 4-5.

The first observation that comes to mind is that the differences between the three groups are surprisingly small considering the importance generally attached in the literature to the differences between these different types of software. Torrisi (1991: 139-140) claimed that mass-market software producers "focused more on publications, fairs, meetings and universities as external sources of innovation". We can see that press, fairs and conferences are indeed important to mass-market software projects in the commercialisation phase and the fairs and conferences also in the idea phase. However, contrary to what Torrisi found these sources are also important to software in need of customisation. The importance of universities and other research institutes is a little higher in the first three phases for massmarket projects, but not especially high.

Customized software, Torrisi continued "rely on lead users, the links with hardware manufacturers, and the acquisition of new personnel. The hiring of new personnel is particularly important for firms specialized in customized software and services." The support 
for these observations is mixed. We can see that customized software projects are more dependent on consultants in the development phase and mass-market projects more dependent in the commercialisation phase. Customized software strong linkage to hardware suppliers is not supported.

Summarizing what Table 11 tells us we can see that customer linkages are the most important link without comparison in all phases for all three types of projects. We can also see that supplier linkages are most important in the development phase to the single client and customisation categories. What competitors do is unimportant to projects made for a single client, and affiliated companies are most important to mass-market projects. Universities and other research institutes are somewhat more important to mass-market projects. Market consultants are less, and technical consultants, more important to single client projects. Technical consultants are most important to customized projects in the idea and development phases, but most important in the commercialisation phase to pure mass-market projects. The press, fairs and conferences are unimportant to single client projects, but very important both in the idea and commercialisation phases to mass- market projects, in need of customisation or not.

Perhaps the differences described by Torrisi would better be corroborated in our material if we as he had focused on companies instead of projects. What we are studying here is one such project, and not the overall linkages important to a firm or to the joint development phases of a software platform. Perhaps, the small differences between the different groups of software can be explained by this fact, but this is a speculation.

We shall now use the same variables as in the previous section to calculate the regression equations for each one of these samples to see whether the factors that drives firms to form external linkages are the same for the three sub-samples as for the sample as a whole. The data that has been used are summarized in Table 12.

Table 12. Drivers of Linkages in Customized versus Mass-Market Projects

\begin{tabular}{|c|c|c|c|c|c|c|}
\hline \multirow[t]{2}{*}{ Measures } & \multicolumn{2}{|c|}{$\begin{array}{c}\text { Groups } A-C- \\
\text { single client } \\
\text { projects } \\
(31 \text { cases }) \\
\end{array}$} & \multicolumn{2}{|c|}{$\begin{array}{c}\text { Groups } D-F- \\
\text { later customised } \\
\text { projects } \\
(37 \text { cases }) \\
\end{array}$} & \multicolumn{2}{|c|}{$\begin{array}{c}\text { Group } G-\text { pure } \\
\text { mass-market } \\
\text { projects } \\
(24 \text { cases }) \\
\end{array}$} \\
\hline & $N$ & Value & $N$ & Value & $N$ & Value \\
\hline $\begin{array}{l}\text { 1a. Extent to which company profitability has been } \\
\text { enhanced } b \text { this project }\end{array}$ & 31 & 3.548 & 36 & 3.734 & 22 & 3.550 \\
\hline 1b. The overall success of the project & 30 & 4.333 & 34 & 4.118 & 24 & 4.021 \\
\hline $\begin{array}{l}\text { 2a. Potential for transfer of knowledge from this project } \\
\text { to subsequent internal projects }\end{array}$ & 30 & 4.167 & 37 & 4.054 & 22 & 3.909 \\
\hline $\begin{array}{l}2 \mathrm{~b} \text {. Product is a relatively new platform that departs } \\
\text { substantially from prior products }\end{array}$ & 28 & 3.607 & 32 & 3.641 & 24 & 4.042 \\
\hline $\begin{array}{l}\text { 2c. Extent to which the feature set of this product differs } \\
\text { from the closest prior development }\end{array}$ & 26 & 3.750 & 34 & 3.588 & 20 & 3.950 \\
\hline $\begin{array}{l}2 \mathrm{~d} \text {. Product performance compared to closest available } \\
\text { competitive product for the market segment }\end{array}$ & 29 & 3.655 & 34 & 3.485 & 23 & 4.000 \\
\hline $\begin{array}{l}\text { Overall estimated newness with respect to the closest } \\
\text { prior product as seen by }\end{array}$ & & & & & & \\
\hline 2e. project team & 30 & 3.600 & 35 & 3.714 & 22 & 3.818 \\
\hline 2f. Company management & 30 & 3.200 & 35 & 3.343 & 22 & 3.545 \\
\hline 2g. customers & 29 & 3.759 & 35 & 3.757 & 22 & 4.091 \\
\hline 2h. competitors & 27 & 3.296 & 33 & 3.091 & 19 & 3.842 \\
\hline
\end{tabular}




\begin{tabular}{|c|c|c|c|c|c|c|}
\hline 2i. Innovation index & 31 & 3.596 & 37 & 3.550 & 24 & 3.961 \\
\hline \multicolumn{7}{|l|}{$\begin{array}{l}\text { Amount of knowledge generated during the project with } \\
\text { regard to: }\end{array}$} \\
\hline 3a. general-purpose knowledge on the product-side & 31 & 1.071 & 37 & 1.300 & 24 & 0.854 \\
\hline 3b. context-specific knowledge on the product-side & 31 & 2.113 & 37 & 1.919 & 24 & 1.646 \\
\hline 3c. knowledge on the market-side & 27 & 1.333 & 37 & 1.892 & 23 & 1.391 \\
\hline 3d. knowledge on the administrative side & 29 & 0.931 & 37 & 0.973 & 23 & 1.022 \\
\hline $\begin{array}{l}\text { 4. Extent to which the firm will likely be able to retain } \\
\text { the knowledge gained as proprietary so that the creation } \\
\text { of later products will be enhanced }\end{array}$ & 29 & 4.138 & 37 & 4.216 & 24 & 3.833 \\
\hline \multicolumn{7}{|l|}{ Absorptive capacity with regard to: } \\
\hline 5a. general-purpose knowledge on the product-side & 31 & 3.242 & 37 & 3.349 & 24 & 3.437 \\
\hline 5b. context-specific knowledge on the product-side & 31 & 2.274 & 37 & 2.527 & 24 & 2.750 \\
\hline 5c. knowledge on the market-side & 27 & 2.426 & 37 & 2.095 & 23 & 2.543 \\
\hline 5d. knowledge on the administrative side & 29 & 2.690 & 37 & 2.679 & 23 & 2.870 \\
\hline 6a. Total number of company employees on global basis & 31 & 29570 & 37 & 15544 & 24 & 7714 \\
\hline $\begin{array}{l}\text { 6b. Number of employees in the country where } \\
\text { interviewee works }\end{array}$ & 31 & 2619 & 37 & 1228 & 24 & 4672 \\
\hline 6c. Ratio of $6 \mathrm{~b} / 6 \mathrm{a}$ (connectivity within large firms) & 31 & 0.223 & 37 & 0.7622 & 24 & 0.7216 \\
\hline 7a. Project team total number & 31 & 11.35 & 37 & 12.08 & 24 & 19.17 \\
\hline 7b. Full-time equivalent man-months used for project & 31 & 268.1 & 36 & 209.2 & 23 & 231 \\
\hline 7c. Ratio of $7 \mathrm{a} / 6 \mathrm{~b}$ & 31 & 0.2168 & 37 & 0.3495 & 24 & 0.842 \\
\hline $\begin{array}{l}\text { 8. Extent to which firm reputation has likely been } \\
\text { enhanced by this project }\end{array}$ & 31 & 3.839 & 37 & 4.162 & 24 & 4.042 \\
\hline $\begin{array}{l}\text { 9. Extent to which this project strengthened linkages } \\
\text { between your company and to the customer(s) will } \\
\text { likely help your firm in the future }\end{array}$ & 31 & 4.065 & 36 & 4.306 & 24 & 4.458 \\
\hline $\begin{array}{l}\text { 10. Extent of personnel knowledge enhancement that } \\
\text { occurred during this project for project team members }\end{array}$ & 31 & 3.800 & 37 & 4.108 & 23 & 4.174 \\
\hline 11a. We buy specialist knowledge & 31 & 3.355 & 36 & 3.333 & 24 & 3.583 \\
\hline $\begin{array}{l}\text { 11b. Instead of developing, we buy knowledge in areas } \\
\text { where other companies are more advanced }\end{array}$ & 31 & 2.968 & 37 & 2.541 & 23 & 2.913 \\
\hline $\begin{array}{l}\text { 11c. We buy knowledge when the knowledge is easy to } \\
\text { transfer from external sources }\end{array}$ & 31 & 3.097 & 36 & 2.500 & 24 & 3.333 \\
\hline $\begin{array}{l}\text { 11d. When new knowledge can be developed in-house } \\
\text { this is usually favoured as I offers more control of the } \\
\text { development process }\end{array}$ & 30 & 3.983 & 37 & 4.108 & 24 & 3.958 \\
\hline $\begin{array}{l}\text { 11e. New knowledge is not bought unless management } \\
\text { is familiar with that specific type of knowledge }\end{array}$ & 30 & 2.233 & 36 & 2.778 & 23 & 2.565 \\
\hline $\begin{array}{l}\text { Estimated percentage of new knowledge needed that } \\
\text { was acquired from external sources }(\%)\end{array}$ & 30 & 25.97 & 34 & 29.42 & 23 & 24.78 \\
\hline Number of 3-5 links in any of the cells & 31 & 7.677 & 37 & 12.590 & 24 & 12.040 \\
\hline Number of different linkages with an importance of 3-5 & 31 & 4.258 & 37 & 6.676 & 24 & 6.542 \\
\hline Number of different types of sources used & 31 & 6.387 & 37 & 7.595 & 24 & 7.458 \\
\hline Number of different linkages used & 31 & 6.903 & 37 & 8.432 & 24 & 8.080 \\
\hline
\end{tabular}

Note: N stands for number of observations. 
The dependent variable will as in the previous regression be the number of actor/source types liked to the project that have a rating of 35 in importance. The alternative dependent variables sometimes gives a slightly higher $\mathrm{R}$ square value. However, the ranking of those independent variables that are significant at the 95 percent confidence level does not, in general, change when different dependent variables are tested. The results of these computations are shown in Table 13 for single client projects, in Table 14 for mass-market projects in later need of customization, and in Table 15 for pure mass-market projects. Finally, the differences between the sample as a whole and the various sub-groups are summarised in Table 16.

Table 13. Determinants of the Number of Important Linkages for the Sub-Group A-C

\begin{tabular}{|c|c|c|c|c|c|c|c|}
\hline Variables & \multicolumn{7}{|c|}{ Estimates } \\
\hline Step & 1 & 2 & 3 & 4 & 5 & 6 & 7 \\
\hline Constant & 4.2800 & -0.62250 & -3.2934 & -0.1363 & -0.8130 & -2.0806 & -2.6977 \\
\hline \multirow[t]{2}{*}{ Dummy variable for group B } & 3.7 & 5.3 & 5.5 & 5.5 & 6.7 & 6.1 & 6.1 \\
\hline & $(2.39)$ & $(2.99)$ & $(3.24)$ & $(3.33)$ & $(3.75)$ & $(3.39)$ & $(3.47)$ \\
\hline \multirow[t]{2}{*}{ 2a. Potential for transfer of $\mathrm{kn}$. } & & 1.12 & 1.14 & 1.07 & 1.56 & 1.24 & 1.49 \\
\hline & & $(1.69)$ & $(1.78)$ & $(\mathbf{1 . 7 2 )}$ & $(2.28)$ & $(1.79)$ & $(2.11)$ \\
\hline \multirow[t]{2}{*}{ 5a. Prior generalpurpose kn. } & & & 0.79 & 0.82 & 1.10 & 1.31 & 1.50 \\
\hline & & & $(1.70)$ & $(\mathbf{1 . 8 3 )}$ & $(2.32)$ & $(2.73)$ & $(3.05)$ \\
\hline \multirow[t]{2}{*}{ 8. Increase in firm reputation } & & & & -0.75 & -0.88 & -1.36 & -1.52 \\
\hline & & & & $(-1.59)$ & $(-1.89)$ & $(-2.47)$ & $(-2.75)$ \\
\hline \multirow[t]{2}{*}{ 11b. Buy when more advanced } & & & & & -0.64 & -0.70 & -0.87 \\
\hline & & & & & $(-1.54)$ & $(-1.72)$ & $(-2.08)$ \\
\hline \multirow{2}{*}{ 2i. Innovation index } & & & & & & 1.14 & 1.28 \\
\hline & & & & & & $(1.54)$ & $(1.74)$ \\
\hline \multirow[t]{2}{*}{ Dummy variable for group A } & & & & & & & -1.30 \\
\hline & & & & & & & $(-1.34)$ \\
\hline Standard Error & 2.55 & 2.46 & 2.37 & 2.30 & 2.24 & 2.17 & 2.13 \\
\hline R Square & 17.98 & 26.43 & 34.37 & 40.91 & 46.68 & 52.09 & 56.02 \\
\hline Adjusted R Square & & & & & & & 28.5 \\
\hline Number of observations & 28 & 28 & 28 & 28 & 28 & 28 & 28 \\
\hline
\end{tabular}

Note: T-Ratios within brackets.

Note: Variables for which the direction hypothesized were supported in bold.

Note: T-ratios significant on a 95 percent level in bold.

Comparing the sample as a whole (groups A-G) with the three sub-groups A-C, D-F, and G, and their sub-groups $\mathrm{C}$ and $\mathrm{F}$, we can observe that the adjusted $\mathrm{R}$ square is markedly lower for group $\mathrm{AG}$ and $\mathrm{A}-\mathrm{C}$, than for the other groups. We can also observe that the equations for both these groups contain dummy variables for some of the sub-groups. The equation for the sample as a whole contains dummies for the sub-group D-F and G. Similarly the group A-C contains dummies for the smaller sub-groups B and A.

The sub-groups that we study are unfortunately too small to be analysed using simple regression analysis and the results of these computations should therefore be interpreted with this fact in mind. We can not claim that these sub-groups do exist in the sense that the factors determining the number and use of external linkages differ between the various sub-groups. However, the dummy variables and the lower $R$ square values received for groups $A-G$ and A-C indicate that this can be the case. The lower adjusted $\mathrm{R}$ square recorded by the groups A$\mathrm{G}$ and $\mathrm{A}-\mathrm{C}$ indicate that those could be explained by the fact that these groups are more heterogeneous. Neither can we claim that the equations presented will hold for a test on a 
Table 14. Determinants of the Number of Important Linkages for the Sub-Group D-F

\begin{tabular}{|c|c|c|c|c|c|c|c|}
\hline Variables & \multicolumn{7}{|c|}{ Estimates } \\
\hline Step & 1 & 2 & 3 & 4 & 5 & 6 & 7 \\
\hline Constant & 3.857 & 10.868 & 10.545 & 8.213 & 10.794 & 11.814 & 11.295 \\
\hline 2f. Newness to management & 0.89 & 1.17 & 1.22 & 1.17 & 1.36 & 1.48 & $\mathbf{1 . 3 5}$ \\
\hline & $(2.40)$ & (3.55) & (3.96) & $(3.92)$ & $(4.20)$ & $(4.54)$ & $(4.17)$ \\
\hline 4. Legal protection & & -1.89 & -2.00 & -1.85 & -2.00 & -2.08 & -2.18 \\
\hline & & $(-3.43)$ & $(-3.88)$ & $(-3.68)$ & $(-3.95)$ & $(-4.18)$ & $(-4.51)$ \\
\hline 7b. Number of man-months & & & $\mathbf{0 . 0 0 2 7}$ & 0.0027 & 0.0026 & 0.0036 & $\mathbf{0 . 0 0 3 7}$ \\
\hline & & & $(2.36)$ & $(2.49)$ & $(2.40)$ & $(2.87)$ & (3.07) \\
\hline 11a. Buy specialist knowledge & & & & 0.56 & 0.44 & 0.36 & 0.26 \\
\hline & & & & $(\mathbf{1 . 8 7})$ & $(1.43)$ & $(1.19)$ & $(0.88)$ \\
\hline 1a. Project profitability & & & & & -0.58 & -0.69 & -0.92 \\
\hline & & & & & $(-1.38)$ & $(-1.67)$ & $(-2.19)$ \\
\hline 7a. Project team size & & & & & & -0.051 & -0.060 \\
\hline & & & & & & $(-1.50)$ & $(-1.81)$ \\
\hline 2a. Potential for kn. transfer & & & & & & & 0.65 \\
\hline & & & & & & & $(\mathbf{1 . 7 3 )}$ \\
\hline Standard Error & 2.84 & 2.44 & 2.28 & 2.18 & 2.15 & 2.10 & 2.03 \\
\hline R Square & 15.69 & 39.47 & 49.25 & 54.86 & 57.86 & 61.21 & 65.34 \\
\hline Adjusted R Square & & & & & & & 55.6 \\
\hline Number of observations & 33 & 33 & 33 & 33 & 33 & 33 & 33 \\
\hline
\end{tabular}

Note: T-Ratios within brackets.

Note: Variables for which the direction hypothesized were supported in bold.

Note: T-ratios significant on a 95 percent level in bold.

Table 15. Determinants of the Number of Important Linkages for the Sub-Group G

\begin{tabular}{|c|c|c|c|c|c|c|c|}
\hline Variables & \multicolumn{7}{|c|}{ Estimates } \\
\hline Step & 1 & 2 & 3 & 4 & 5 & 6 & 7 \\
\hline Constant & 4.881 & 10.710 & 8.848 & 11.442 & 8.381 & 11.849 & 11.960 \\
\hline \multirow[t]{2}{*}{ 7a. Project team size } & $\mathbf{0 . 0 7 3}$ & 0.085 & 0.092 & 0.108 & 0.100 & 0.105 & 0.108 \\
\hline & $(3.44)$ & $(5.08)$ & $(5.74)$ & $(6.08)$ & $(5.83)$ & $(6.41)$ & $(7.30)$ \\
\hline \multirow[t]{2}{*}{ 11d. In-house dev. for control } & & -1.55 & -2.01 & -2.24 & -2.05 & -2.13 & -2.08 \\
\hline & & $(-3.68)$ & $(-4.36)$ & $(-4.91)$ & $(-4.67)$ & $(-5.13)$ & $(-5.55)$ \\
\hline \multirow[t]{2}{*}{ 2a. Potential for transfer of kn. } & & & 0.91 & 0.94 & 0.97 & 0.93 & 0.92 \\
\hline & & & $(\mathbf{1 . 9 1 )}$ & $(2.08)$ & $(2.27)$ & $(2.33)$ & $(2.54)$ \\
\hline \multirow[t]{2}{*}{ 5b. Prior context -specific kn. } & & & & -0.77 & -0.80 & -1.08 & -1.26 \\
\hline & & & & $(-1.73)$ & $(-1.91)$ & $(-2.54)$ & $(-3.21)$ \\
\hline \multirow[t]{2}{*}{ 11b. Buy when more advanced } & & & & & $\mathbf{0 . 7 2}$ & 0.91 & 0.94 \\
\hline & & & & & $(\mathbf{1 . 7 8})$ & $(2.31)$ & $(2.64)$ \\
\hline \multirow[t]{2}{*}{ 11a. Buy specialist knowledge } & & & & & & -0.80 & -1.27 \\
\hline & & & & & & $(-1.74)$ & $(-2.69)$ \\
\hline \multirow[t]{2}{*}{ 11c. Buy kn. easy to transfer } & & & & & & & 0.63 \\
\hline & & & & & & & $(2.05)$ \\
\hline Standard Error & 3.00 & 2.33 & 2.17 & 2.06 & 1.93 & 1.81 & 1.63 \\
\hline R Square & 38.39 & 64.84 & 71.04 & 75.61 & 79.85 & 83.45 & 87.49 \\
\hline Adjusted R Square & & & & & & & 80.8 \\
\hline Number of observations & 21 & 21 & 21 & 21 & 21 & 21 & 21 \\
\hline
\end{tabular}

Note: T-Ratios within brackets.

Note: Variables for which the direction hypothesized were supported in bold.

Note: T-ratios significant on a 95 percent level in bold. 
larger sample of similar projects, but we can see the results of our computations on these smaller groups as hypotheses that can be tested on larger samples of similar software development projects.

Turning to the independent variables that have entered our equations we can observe that the coefficients of the variables that entered our equation in general have the direction that we anticipated. It is interesting to notice that 'prior general-purpose knowledge' (variable 5a) had a positive coefficient and 'prior context-specific knowledge' (variable 5b) a negative precisely as Torrisi (1991) hypothesized. High prior general-purpose knowledge gives absorptive capacity, while high prior context-specific knowledge in pure mass-market project gives less reason to form external linkages to acquire context-specific knowledge about the users.

The coefficients that did not take the direction that we anticipated were enhancement of firm reputation (variable 8), personnel knowledge enhancement (variable 10), and the profitability of the software project (question 1a). Thus, the coefficient tells us that software development projects that rely less on external linkages are more profitable. This result seems difficult to interpret, but perhaps is there an optimal level of external linkages in each project which too many of the projects in our sample have passed. Compare Håkansson's $(1979 ; 1980)$ who studied Swedish manufacturing companies found that the companies with a lower or a higher than average share of external cooperation in their product development projects were less profitable and had a lower growth rate.

We can also observe that there are a relatively small number of variables that pop up in several of the equations. We can also observe that the same variables turns up in the equations for both the sample as a whole and sub-group DF, mass-market project in need of later customization. Of 31 independent variables only 13 appears in the equations of the five largest groups in Table 16.

Important variables seem to be the innovation index (variable 2i), and especially its components 'overall estimated newness with respect to the closest prior product as seen by company management' (variable $2 \mathrm{f}$ ) and 'the potential for transfer of knowledge from this project to other subsequent internal projects' (variable 2a). The former can mostly be exchanged by the strongly correlating variable newness to project team (variable 2e), and the latter can be interpreted as a measure of relatedness. It is also interesting to notice that the three most common measures of innovativeness in research on product development are constructs based on product innovativeness, radicalness (discontinuous), and newness to firm (Garcia and Calantone, 2002).

One can observe that the newness to company management (variable 2f) and other measures of innovativeness tend to rank high for the two groups of later customised software projects. What distinguishes customised software from the other two groups is that a mass-maket software later on has to be customised to a new customer/market. The software is either a software package that need customisation to be installed, or a customized software that need to be adapted for a mass-market. When such modifications imply a large step in technological knowledge then more external linkages seem to be needed. When new market knowledge has to be developed in a software project it looks like this means that also new technical solutions and knowledge have to be developed, which seems reasonable as technical solutions are used to adapt the software for a new type of customers. 
Table 16. The Sample and Its Sub-Groups Compared

\begin{tabular}{|c|c|c|c|c|c|c|c|c|c|}
\hline Sample & $A-G$ & $A-C$ & $A$ & $B$ & $C$ & $D-F$ & $D$ & $F$ & $G$ \\
\hline Steps & 7 & 7 & & & 7 & 7 & & 6 & 7 \\
\hline Constant & 7.217 & -2.6977 & & & 1.3636 & 11.295 & & 15.52 & 11.960 \\
\hline \multirow[t]{3}{*}{ Variable 1} & 4 & D: B & & & $1 \mathrm{a}$ & $2 f$ & & 4 & $7 \mathrm{a}$ \\
\hline & -1.63 & 6.1 & & & -0.77 & 1.35 & & -2.77 & 0.108 \\
\hline & $(-4.47)$ & $(3.47)$ & & & $(-1.59)$ & $(4.17)$ & & $(-4.81)$ & $(7.30)$ \\
\hline \multirow[t]{3}{*}{ Variable 2} & $2 f$ & $2 \mathrm{a}$ & & & 10 & 4 & & $2 f$ & $11 \mathrm{~d}$ \\
\hline & 0.72 & 1.49 & & & -0.66 & -2.28 & & 1.50 & -2.08 \\
\hline & $(3.20)$ & $(2.11)$ & & & $(-1.84)$ & $(-4.51)$ & & (4.13) & $(-5.55)$ \\
\hline \multirow[t]{3}{*}{ Variable 3} & D: D-F & $5 a$ & & & $5 a$ & $7 b$ & & $1 \mathrm{a}$ & $2 \mathrm{a}$ \\
\hline & 2.23 & 1.50 & & & 1.63 & 0.0037 & & -1.08 & 0.92 \\
\hline & $(3.30)$ & $(3.05)$ & & & $(3.91)$ & (3.07) & & $(-2.45)$ & $(2.54)$ \\
\hline \multirow[t]{3}{*}{ Variable 4} & $7 b$ & 8 & & & $3 c$ & $11 \mathrm{a}$ & & $7 b$ & $5 b$ \\
\hline & 0.00132 & -1.52 & & & 3.97 & 0.26 & & 0.0036 & -1.26 \\
\hline & $(1.96)$ & $(-2.75)$ & & & $(4.94)$ & $(0.88)$ & & $(2.82)$ & $(-3.21)$ \\
\hline \multirow[t]{3}{*}{ Variable 5} & $11 a$ & $11 \mathrm{~b}$ & & & $3 b$ & 1a & & $7 a$ & $11 \mathrm{~b}$ \\
\hline & 0.40 & -0.87 & & & -1.78 & -0.92 & & -0.0074 & 0.94 \\
\hline & (1.96) & $(-2.08)$ & & & $(-2.60)$ & $(-2.19)$ & & $(-2.16)$ & $(2.64)$ \\
\hline \multirow[t]{3}{*}{ Variable 6} & D: $G$ & $2 \mathrm{i}$ & & & $5 d$ & $7 \mathrm{a}$ & & $2 \mathrm{a}$ & $11 \mathrm{a}$ \\
\hline & 1.23 & 1.28 & & & 1.74 & -0.060 & & 0.58 & -1.27 \\
\hline & $(1.67)$ & $(1.74)$ & & & $(2.85)$ & $(-1.81)$ & & $(1.40)$ & $(-2.69)$ \\
\hline \multirow[t]{3}{*}{ Variable 7} & $7 \mathrm{c}$ & D: A & & & 8 & $2 a$ & & & $11 \mathrm{c}$ \\
\hline & -0.60 & -1.30 & & & -0.92 & 0.65 & & & 0.63 \\
\hline & $(-1.59)$ & $(-1.34)$ & & & $(-1.25)$ & $(1.73)$ & & & $(2.05)$ \\
\hline Stand. Error & 2.70 & 2.13 & & & 1.63 & 2.03 & & 2.10 & 1.63 \\
\hline R Square & 37.71 & 56.02 & & & 85.04 & 65.34 & & 67.80 & 87.49 \\
\hline Adj R Square & 29.0 & 28.5 & & & 70.1 & 55.6 & & 49.9 & 80.8 \\
\hline T-ratio $95 \%$ & $1.671(60)$ & 1.697 & & & 1.740 & $1.684(40)$ & & 1.699 & 1.725 \\
\hline Sample size & 92 & 31 & 10 & 4 & 17 & 37 & 6 & 31 & 24 \\
\hline Observations & 82 & 28 & & & 15 & 33 & & 27 & 21 \\
\hline Miss. values & 10 & 3 & & & 2 & 4 & & 4 & 3 \\
\hline
\end{tabular}

Note: T-ratios within brackets.

Note: Variables for which the direction hypothesized were supported in bold.

Note: T-ratios significant on a 95 percent level in bold.

Note: D: B stands for Dummy variable for group B.

Another measure that tends to turn up in our computations is our measure of legal protection (variable 4). Fewer links are formed if the company is likely to be able to retain the knowledge gained as proprietary and use this knowledge in future products. Thus, the lack of legal protection for computer software contributes to the formation of many external linkages in that industry. A measure which might serve the same function in the pure mass-market equation is a company's preference for in-house development to retain control over the development process (variable 11d).

Yet other types of measures that appear in our equations are the size of the project team (variable 7a) and the number of man-months needed to develop the software (variable $7 \mathrm{~b}$ ). These two measures can generally substitute each other, i.e. if one of them is omitted the other one will enter the equation. Their inclusion tells us that larger project teams forms more linkages. This is not unreasonable as there must be a correlation between the absorptive capacity of the project team and both the number of people in the team and the number of 
man-months The number of people in the team as more people means more personal linkages with external actors and the number of man-months is also involved as it takes time to identify external knowledge and partners with which one can cooperate and acquire knowledge.

We have crystallised five independent measures of company knowledge strategy. The two that appears in more than one equation are 'We buy specialist knowledge' (variable 11a) and 'Instead of developing, we buy knowledge in the areas where other companies are more advanced' (variable 11b). These results should not be unexpected in an industry with such a fast technical development as the computer software industry. High-tech companies have long favoured buying whenever some other firm is more advanced and willing to sell. An important aspect in pure mass-market software projects was that in-house development was favoured as it offered better control of the development process (variable 11d), possibly as legal protection is weak for software products. Company strategy seems to be an important factor influencing the choice to form external linkages.

\section{Differences between Projects with Few or Many Linkages - A Qualitative Approach}

Our regression exercises have shown that the number of linkages correlate with such factors as project profitability, innovativeness, possibility to retain ownership to the new knowledge that is being developed, company size, project size, and the image effect of external linkages. However, the correlations are generally weak and vary from one group of projects to another. There are large software companies with many linkages, and specialized companies developing complex new software with relatively few linkages. The causes of such anomalies are difficult to understand through statistical analyses. However, by scrutinizing the answers given in individual projects and the case descriptions the answers to the different questions are coherent and make sense. Thus there is a logic behind the answers, but there appears to be so many different types of software projects and situations that this logic becomes difficult to extract by means of statistics on this relatively small sample. It therefore becomes interesting to compare the case descriptions case by case to see if there are any factors which can explain why so many cases deviate from the general pattern, and to see if there are certain archetypes that can be identified.

Doing this we found that only a few linkages were needed

- $\quad$ in small and simple software development projects

- when the need for many different external market linkages is low, as when the software is developed for internal use, a specific customer, or, small niche market

- $\quad$ the company has as a strategy to develop in-house, at least the type of knowledge that the project in question represents as this knowledge is considered core knowledge to the company

Similarly, many linkages were needed

- $\quad$ in large innovative and complex software development project

- $\quad$ when essential knowledge necessary to develop the software does not exist in-house; usually when a small company develops a software product that is too large and 
complex for the size of the company, or a company develops software in an area in which it does not have previous experience

- when a company outsources routine work due to a shortage of programmers

- the company has as a strategy to buy new knowledge whenever possible and focus on being good at integrating various software knowledge and systems, a so called 'system company', which in its extreme form can become a project-based company

The seven types of companies described above represent archetypes for software development. There are good examples of all these seven archetypes in the sample, although most of the cases are far from that clear-cut. Many of the cases exhibit traits of several of the archetypes represented, and therefore it is impossible to sort all cases into seven mutually exclusive groups. Perhaps it would be possible to sort them into groups exhibiting traits of the archetypes identified, but then the total number of cases would surpass by far 92 . Having seen this we have chosen to specify the factors behind the archetypes. The result of this analysis is summarized in Table 17.

Table 17. Factors Affecting the Number of Linkages Used in the Development of Software

\begin{tabular}{|l|l|l|}
\hline & Few linkages & Many linkages \\
\hline Software project & Simple & Complex and/or Innovative \\
\hline Software market & Existing market & New market \\
\hline External knowledge & Not available & Available \\
\hline In-house knowledge & Sufficient and available & Insufficient \\
\hline Company strategy & Develop in-house & Buy if possible \\
\hline
\end{tabular}

Starting with the software project category, it is quite evident that simple, which often also means small, software projects can be developed by fewer people using less specialist knowledge. Fewer people and organizations with specialist knowledge need to be involved, than when an innovative and/or complex new software is developed. Complex software requires the integration of many different software packages and technologies that are only available from different sources. Firms developing innovative software often have connections with universities and patent offices which add to the number of linkages used.

Turning to the market, software companies developing software for an existing market do not necessarily hire market consultants. The best examples of this are two cases when large software companies developed a software programs for internal use. Linkages were few as there are no external market links. If the program works well both companies intend to make a new version of the program for sale and then of course they have to activate or develop market links suitable for that specific software.

Another group of firms which often tend to have few linkages are firms that develop software for a specific industry, as for instance the oil industry or large pharmaceutical companies. Such software is specialized and the companies have long-term relations with those companies in the industry with which they are associated. The sample contains a few good examples of such firms producing a specialized type of software which seems quite advanced for a limited number of users which they have long-time relations with.

Hewlett Packard, Germany, developed a user administration system for a telecom company. The program took nine people 72 man-months to develop. The only external linkage used was the one with the telecom company which had ordered the system. The 
need for additional external linkages was low as the company had excess to all the knowledge needed inside the Hewlett Packard Group.

The German subsidiary of a large U.S. hardware and software group developed a software program to control the work flow and status of single production orders in some of its production plants world-wide. The software was a real-time system. It took nine people 162 man-months to develop, and the number of linkages was few as the company was a part of a large group and the product was intended only for internal use. Thus there were no market linkages, only linkages to one supplier and one hardware manufacturer.

Another important factor is, of course, the availability of external knowledge. If knowledge cannot be purchased externally it has to be developed in-house. Large diversified software groups, such as the ones in the examples, have much of this software knowledge in-house. Instead of forming links to other companies they can access the knowledge needed internally. One could therefore expect that companies located in areas of many software firms would have more linkages. However, as is shown in Appendix companies in countries with many software firms did not form more linkages, than those in less developed software regions. This contradicts such a proposition. Location is obviously not the only factor explaining the propensity to form linkages.

Furthermore, in some cases a lack of in-house resources seems to cause companies to form external linkages for non-core projects. The cases gave an example of one large company in which this was very evident. They extensively used consultants and external sub-contractor in one very large software project to shorten the development time. The company experienced a shortage of software programmers and the software developed was not a part of their core competence.

The last factor was company strategy. A company can choose to buy or develop. Let us illustrate with two cases from the pilot study.

Pilot case 1 was one of the four companies in the pre-study. It was a Swedish software security company with about 100 employees when it was acquired by an American software security company. The Swedish company had its roots in the military sector. Important customers were the OEM customers were HP and Sun, and large U.S. banks, companies and hospitals; important cooperative partners HP and Sun. However, to protect their security solutions they preferred to do as much as possible of the development work concerning their security programs in-house, and the number of linkages was therefore relatively low. The CEO and the technical director estimated that 80-90 percent of all the development work was done in-house.

The company's strategy as a security company was to keep as much as possible of the knowledge of the security solutions that they created in-house, and therefore they also had to do the bulk of the development work in-house.

Another type of company with few linkages is the sub-contractor. One example of this in the sample is a very successful East-European software company which developed a software package that was marketed under the brand name of a large American computer hardware and software company. Since they had sold the rights to this specific software package to their American partner they did not had to develop any other market links with regard to this software. 
On the other side of the spectrum we had an extremely profitable small Swedish software firm. They had developed a software product that recorded who and on which printer employees were printing. It was a mass-market program which could be downloaded from the web. Instead of hiring people for the company they hired people for a project.

Pilot case 2 was a small, very profitable company founded in 1995. It had developed four products in different versions. The most well-known was a program which made it possible for companies and universities to control who was printing what. The company was owned and run buy the three founders. Their core competences were the system knowledge and know-who necessary to acquire external knowledge. The program was constantly upgraded, and one such project could involve 20-30 people. The company was to a large extent project-based, and many linkages were used. Today the company has sold 100,000 licenses world-wide, and has emerged as one of the world's leading developers of system administration software to the fast-growing Microsoft Windows NT/2000-based server market.

When a small firm carries out a project which is too complex for a company of their size they often have to focus on the knowledge needed to manage the project, identify and to integrate the knowledge needed from the external sources. The cases gave several examples of such small system companies which had to form many linkages to be able to develop the software they are marketing. They have had to act like system companies. The sample also gives several examples of large firms developing complex software with a strategy of buying whenever suitable software exist from external sources. An important consideration here is that they develop very complex software which integrated the use of many different technologies. With regard to software development they act as system integrators. As such they are experienced in identifying and acquiring external knowledge.

Aircraft Tech Systems is a part of the Aircraft Group which produces aircraft, weapon systems, electronic and software for military use and the space industry. The core skill of the company is system integration. This includes integrating high technology commercial, off-the-shelf hardware, software, and applications into seamless solutions. As many other aircraft companies, the Aircraft Group terms itself a system company. The software system we studied was a single client coastguard (detection and fire control system) system. A team of 20 people spent 780 man-months for the project, and it was estimated that 40 percent of the development work needed for such projects was acquired from external sources. Although it was a single client project the number of linkages used was very high, as the company sees itself as a system company. The total number of linkages recorded were 17, whereof those with what is classified as relating to markets were the most important and especially the customer.

System integrators are often called system companies (Bonaccorsi et al., 1999). The core competence of a system company is to understand what knowledge is needed, and to acquire and integrate this knowledge in their product. System companies are common in industries developing complex products that integrate many technologies such as aircraft companies, and also among small firms in high-tech industries that have to focus on buying and integrating technologies to be able to develop their products. In the extreme form, system companies becomes project-based companies, i.e. they hire people to carry out the project. Examples of project-based companies can be found in the film and entertainment industry. 
Earlier research has identified correlations between the number of linkages and such variables as company size, innovativeness, etc. Studying individual cases one understands that both small and large firms can need many linkages to develop software. To what extent one will find correlations between, for instance, the number of linkages and company size depends to a large extent on the composition of the sample. When, as in our study, the sample consists of many small and medium-sized companies undertaking projects too large and complex to be developed mainly using internal knowledge, the correlation between, for instance, size and linkages becomes weak. The case-by-case analysis also shows that the buy-or-develop decision in software development can not be explained by market and technology factors alone. It is a strategic decision and it is largely decided by the preferences of project and/or company management.

\section{Summary}

Harder competition and increasingly complex products that have to be developed in shorter and shorter time frames have forced firm to increasingly rely on external knowledge acquisition to bring new products to the market (Hagedoorn, 2002). In fact,

[o]ne of the most robust results from recent European surveys on innovation is that firms which are involved in formal cooperation arrangements tend to innovate significantly more: they have much higher shares of new products in their sales profiles than firms which do not undertake collaborative R\&D or technology development. (Sandven, 1996: 3, referring to European Commission, Green Paper on Innovation, Bulletin of the European Union Supplement 5/95, Table 22, p. 92)

Technical linkages have been shown to be highest in emerging and dynamic industries, and Hagedoorn (1993) points out the computer software industry as the best example of an industry in which firms external knowledge acquisition is especially important. The purpose of this paper has been to describe and analyse the use of external sources of knowledge in a sample of computer software projects.

When comparing the results of this study with that of other studies one should remember that this study focuses on computer software projects. Firstly, there are many studies of networking and external knowledge acquisition but the focus is exclusively on the linkages that firms have, and not the ones that internal projects have. Secondly, there are many studies of product development addressing these issues, but few of computer software development.

Although there are few really comparable studies the analysis of our sample makes it possible to state that a greater number of linkages are used in software development projects, than in development projects in the tangible product manufacturing industry. In our sample there was not one project that did not make use of external sources of knowledge, and the average number of linkages was seven. Still these figures relates to projects and not companies. This makes these figures very high compared to earlier studies of manufacturing firms. In addition, the average linkage formed in software development projects is of shorter duration, than those formed in the tangible hardware projects, and the most important overall linkages are without comparison those formed with customers. Linkages to suppliers, competitors, hardware manufacturers, fairs/conferences, technical consultants, the press, affiliated companies, and market consultants, are all considered more important, than those formed with universities, other research institutes, patent offices, or financial promoters. 
Linkages to customers are the most important linkages in all the four phases of the simplified product development process used in this study in which various levels of innovativeness has not been distinguished. Also important in the idea phase are competitors and fairs/conferences, in the decision phase competitors, in the development phase technical consultants, suppliers, and affiliated companies, and in the commercialisation phase fairs/conferences, the press, and affiliated companies.

We have tried two ways of explaining the number and importance of external linkages in software development projects; firstly, through deduction and regression analyses, and secondly, through analyses of case descriptions and induction.

The regression analyses show that the main sample of 92 cases consists of several subsamples. The regression equations for these different sub-samples show that the factors determining the use of external linkages vary by type of software development project. However, it is not possible to prove that these differences do exist as the sub-samples are too small. The result of these computations should therefore be seen as hypotheses that can be tested on future larger samples of similar projects.

A relatively small number of the total number of independent variables turns up as important in several of the equations. Positively related with external linkages are various measures of product nnovativeness such as newness to management and the potential for transfer the knowledge developed in future software projects. Different measures of innovativeness are the measures that in correlation analyses are most strongly related to the number of linkages, although it does not always appears in our regression equations. The more innovative a project is the more of the new knowledge has to be developed internally or acquired externally. Another measure that is positively associated with external linkages is project size measured as project team size and number of man-months. Large projects need perhaps more linkages as are more complex, and large projects have more absorptive capacity to identify and make use of external knowledge.

Negatively associated is legal protection. The weaker legal protection is the more linkages there are. It seems like weak legal protection for software contributes to the computer software industry having many external linkages. Also the overall knowledge strategy of the company seems important. Many software firms buy specialist knowledge, and prefer to buy new knowledge instead of developing whenever somebody else is more advanced. In that way, they behave in a similar manner as many other high-tech firms, when the technology is rapidly changing.

Our second approach to explain the number and importance of external linkages was inductive. By studying the case descriptions collected in a case-by-case fashion, it is not too difficult to understand why more linkages have been used in some of the projects, than in other. Doing so we have identified seven archetypes, such as system companies, which sometimes borders onto project-based companies, and the large firm that has excess to most of the knowledge needed internally and possibly also develops a given program for internal use. From this we can extract the following factors influencing the formation and use of external linkages: the innovativeness and complexity of the software project, the newness of the market, the availability of needed knowledge in-house, availability of needed knowledge externally, and company strategy. In most software development projects these five factors typically mix, sometimes forming clear cut archetypes of the types previously mentioned. 


\section{Appendix}

The study has shown that software development projects differ from hardware development projects when it comes to the formation and use of external sources of knowledge. They also differ in that cooperation between small and large firms is much more common, and that the cooperative partner or customer is not necessarily geographically a neighbour. Neither does it look like companies located in areas with more software firms use more linkages in their software projects.

Cooperation between small and large firms. It is generally believed that small firms do not cooperate with large firms, or at least that such cooperation is difficult (Rothwell and Dodgson, 1991; MacPherson, 1997). Rothwell and Dodgson (1991: 135) came from their studies and review of the literature to the conclusion that "few innovative SMEs form linkages with large firms", and they continue: "The major reason why such collaborations are not formed is the size of the management problems involved for SMEs." This is an observation that has been confirmed to hold also for US SMEs (MacPherson, 1997). Only $13 \%$ of the firms having significant external technical links with other companies had such links with larger or major companies. The majority of the links were with companies of the same size class.

Software firms differ also in this respect in that cooperation between small and large companies is very common. The reason for this is that software firms do not only compete with software firms offering software that can run in for instance a Microsoft environment, but also with firms producing competing software for an Apple or Linux environment. Microsoft is therefore eager to promote and help smaller firm producing software that runs on Microsoft's operative system. Such partnering helps Microsoft make its operative system more useful and more widely spread. Microsoft is a successful so called 'web shaper' (Hoch et al., 1999). There are many such partner webs within the many segments of the software industry, and what is specific for the computer software industry is that computer software firms compete both on web components and between webs. There are many examples of such linkages between web creators and software projects in our sample.

The geographical location of cooperating partners. Another difference is that traditional manufacturing firms prefer to cooperate with local firms (Håkansson, 1979; MacPherson, 1997). Håkansson (1979) found that about $80 \%$ of the relations were with other Swedish firms, and that only a few percent of the relations were with non-European firms. Although the material is incomplete there is no question that linkages between parties on different continents are much more frequent in the computer software industry. A good example of this was supplied by one of the companies in the pre-study. When that company was formed in 1984 the founder went to an American fair to try to form relations with US customers. That failed, but the founder was approached by a representative of a Japanese company. The Japanese firm was obviously satisfied with the software as it later ordered and paid for the development of a new software program. Ten years later the firm had become the market leader in Japan in their small specific software niche, and is today the market leader worldwide in the same market niche.

The case studies gives several examples of that the gradual process of internationalisation described by the classical internationalisation model (Johansson and Vahlne, 1977) does not 
always apply to computer software firms. Internationalisation can, as in the case described, go directly from Sweden to Japan, or some other foreign country, and a European software product can be marketed in the US or Japan before it is marked in Europe. Firms may cooperate to develop new software only after having been in contact for a half year or less, and cooperate via the Internet with a firm on another continent. The process of internationalisation can be very different from what we are used to from the tangible product manufacturing industry.

The supply of external knowledge. Computer software firms located to areas with clusters of software firms like Cambridge, Stockholm and Helsinki, could be assumed to have more external linkages and rely more on external sourcing, than firms in countries without such large clusters. To test this hypothesis we have counted the number of linkages that firms in each one of the 19 countries represented in the sample had. See Table 18.

Table 18. The Companies Studied and Their Origin

\begin{tabular}{|c|c|c|c|c|c|c|}
\hline Country & Numbe & of cases & Average number & lations & Average numl & tions \\
\hline Spain & & & 489 & & & \\
\hline Italy & 6 & & 5.17 & & 7.33 & \\
\hline France & 6 & 20 & 4.33 & 4.80 & 7.33 & 6.80 \\
\hline & & & & & & \\
\hline Germany & 6 & & 4.00 & & 5.50 & \\
\hline Austria & 3 & 9 & 7.33 & 5.11 & 11.00 & 7.33 \\
\hline Reloium & & & & & 60 & \\
\hline & 4 & & 7.00 & & 6.60 & \\
\hline Holland & 4 & 8 & 4.75 & 5.22 & 5.50 & 6.11 \\
\hline & & & & & & \\
\hline$U . K$. & $\overline{2}$ & $\overline{2}$ & 8.00 & 8.00 & 9.50 & 9.50 \\
\hline & & & & & & \\
\hline Finland & 5 & & 6.50 & & 6.80 & \\
\hline Norway & 2 & 7 & 3.00 & 4.57 & 5.50 & 6.43 \\
\hline & & & & & & \\
\hline Russia & 2 & & 7.50 & & 9.00 & \\
\hline Lithuania & 1 & & 7.00 & & 7.00 & \\
\hline Slovenia & 1 & & 3.00 & & 3.00 & \\
\hline Estonia & $\overline{2}$ & 6 & 7.00 & 5.33 & 12.00 & 8.50 \\
\hline & & & & & & \\
\hline$U S A$ & 2 & & 6.50 & & 8.00 & \\
\hline Canada & 4 & & 11.00 & & 8.75 & \\
\hline Australia & 2 & & 1.50 & & 3.50 & \\
\hline Peru & 1 & 9 & 10.00 & 5.82 & 11.00 & 8.00 \\
\hline & & & & & & \\
\hline Sweden & 31 & 31 & 6.63 & 6.63 & 8.97 & 8.97 \\
\hline Total/Average & $\overline{92}$ & $\overline{92}$ & 5.826 & 5.826 & 7.826 & 7.826 \\
\hline
\end{tabular}

The second column shows the number of cases per countries, and the third column the number of cases per group of countries. To the far right we have the average number of relations, and in the middle the average number of relations considered important enough to be ranked 3-5. The number of cases per country and group is too small for statistical analysis. However, one can see that Swedish companies have on average one more linkage, than the rest of the sample. Other countries which companies use many external sources are Austria, the UK, Finland, Russia, Lithuania, Estonia, the USA, Canada and Peru. However, the fact that the cases from countries like Russia, Lithuania, Estonia, and Peru, contradicts the hypothesis that access to many computer software firms in the neighbourhood would increase the number of linkages used to acquire external knowledge. The supply of external knowledge is perhaps important, but it is only one of several factors important to the use of external relations in computer software development projects. 


\section{References}

Auster, E.R. (1992). The relationship of industry evolution to patterns of technological linkages, joint-ventures, and direct investment between U.S. and Japan. Management Science, 38(6), 778-792.

Baetjer, H. (1998). Software As Capital: An Economic Perspective On Software Engineering. Los Alamitos, CA: IEEE Computer Society Press.

Bonaccorsi, A., Pammolli, F., \& Tani, S. (1996). The changing boundaries of system companies. International Business Review, 5(6), 539-560.

Bonaccorsi, A., Pammolli, F., Paoli, M., \& Tani, S. (1999). Nature of innovation and technology in system companies. $R \& D$ Management, 29(1), 57-69.

Burgelman, R.A. (1984). Designs for corporate entrepreneurship in established firms. California Management Review, 26(3), 154-166.

Chandra, B., \& MacPherson, A. (1994). The characteristics of high-technology manufacturing firms in a declining industrial region: an empirical analysis from western New York. Entrepreneurship and Regional Development, 6, 145-160.

Cohen, W.M., \& Levinthal, D.A. (1990). Absorptive capacity: A new perspective on learning and innovation. Administrative Science Quarterly, 35(1), 128-152.

Cooper, R.G. (1979). The dimensions of industrial new products success and failure. Journal of Marketing, 43(Summer), 93-103.

Cugola, G., \& Ghezzi, C. (1998). Software processes: a retrospective and a path to the future. Software Process: Improvements and Practice, 4(3), 101-123.

Cyert, R.M., \& March, J.G., (1963). A Behavioral Theory of the Firm. Englewood Cliffs, N.J.: Prentice-Hall.

Dussauge, P., Hart, S., \& Ramanantsoa, B. (1992). Strategic Technology Management. New York: John Wiley \& Sons, Inc.

Davidson, J.H. (1976). Why do most new consumer brands fail? Harvard Business Review, 57(2), 117-122.

Dodgson, M. (1994). Technological collaboration and innovation. In M. Dodgson and R. Rothwell (Eds.), The Handbook of Industrial Innovation. Hants, U.K.: Edward Elgar.

Dutta, S., Van Wassenhove, L.N., \& Kulandaiswamy, S. (1998). Benchmarking European software management practice. Communication of the ACM, 41(6), 77-86.

Fitzgerald, B. (1998). An empirical investigation into the adoption of systems development methodologies. Information \& Management, 34, 317-328.

Garcia, R., \& Calantone, R. (2002). A critical look at technological innovation typology and innovativeness terminology: a literature review. Journal of Product Innovation Management, 19, 110-132.

Granstrand, O., Bohlin, E., Oskarsson, C., \& Sjöberg, N. (1992). External technology acquisition in large multi-technology corporations. $R \& D$ Management, 22(2), 111-133.

Hagedoorn, J. 1993. Understanding the rationale of strategic technology partnering: Interorganizational modes of cooperation and sectoral differences. Strategic Management Journal, 14, 371-385.

Hagedoorn, J. (2002). Inter-firm R\&D partnership: an overview of major trends and patterns since 1960. Research Policy, 31(4), 477-492.

Hagel, J., III \& Singer, M. (1999). Net Worth. Boston: Harvard Business School Press.

Hauschildt, J. (1992). External acquisition of knowledge for innovations - a research agenda, $R \& D$ Management, 22(2), 105-110.

den Hertog, J.F., \& van Sluijs, E. (1995). Managing knowledge flows: a key role for personnel management. In L.E. Andreasen, B. Coriat, F. den Hertog \& R. Kaplinsky 
(Eds.), Europe's Next Step: Organisational Innovation, Competition and Employment (pp. 175-195). Ilford, UK: Cass.

den Hertog, J.F., \& Huizenga, E. (2000). The Knowledge Enterprise: Implementation of Intelligent Business Strategies. London: Imperial College Press.

Hoch, D.J., Roeding, C.R., Purkert, G., \& Lindner, S.K. (1999). Secrets of Software Success: Management Insights from 100 Software Firms around the World. Boston, MA: Harvard Business School Press.

Håkansson, H. (1989). Corporate Technological Behaviour: Coorporation and Networks. London: Routledge.

Håkansson, H. (1990). Technological collaboration in industrial networks. European Management Journal, 8(3), 371-379.

Johanson, J., \& Vahlne, J.-E. (1977). The internationalization process of the firm: A model of knowledge development and increasing foreign market commitments. Journal of International Business Studies, 8(Spring/Summer), 23-32.

Jones, G.K, Lanctot, A., \& Teegen, H.J. (2000). Determinants and performance impacts of external technology acquisition. Journal of Business Venturing, 16(3), 255-284.

Kazanjian, R.K., \& Drazin, M.J. (1987). Implementing internal diversification: Contingency factors for organizational design choices. Academy of Management Review, 12(2), 342354.

Klein, S.J., \& Rosenberg, N. (1986). An overview of innovation. In R. Landau \& N. Rosenberg (Eds.), The Positive Sum Strategy: Harnessing Technology for Economic Growth. Washington, DC: National Academy Press.

Kurokawa, S. (1997). Make-or-buy decisions in R\&D: Small technology based firms in the United States and Japan. IEEE Transactions on Engineering Management, 44(2), 124134.

Link, A.N., \& Tassey, G. (1987). Strategies for Techology-based Competition: Meeting the New Global Challenge. Lexington, MA: Lexington Books.

Macdonald, S. (1995). Learning to change: An information perspective on learning in the organization. Organization Science, 6(5), 557-568.

Macdonald, S. (1998). Information for Innovation: Managing Change from an Information Perspective. Oxford: Oxford University Press.

MacPherson, A. (1997). The contribution of external service inputs to the product development efforts of small manufacturing firms. R\&D Management, 27(2), 127-144.

Matusik, S. F., \& Hill, C. W. L. (1998). The utilization of contingent work, knowledge creation, and competitive advantage. Academy of Management Review, 23(4), 680-697.

Mowery, D. C. (1996). The International Computer Software Industry (Ed.). New York: Oxford University Press.

Nonaka, I., \& Takeuchi, H. (1995). The Knowledge-Creating Company. New York: Oxford University Press.

Paroline, C. (1990). Growth paths for small and medium high-tech companies. Paper presented at the Symposium on Growth and Development of Small High-Tech Businesses, Cranfield Institute of Technology.

Roberts, E.B. (1995). Benchmarking the strategic management of technology - I. ResearchTechnology Management, (1), 44-56.

Rothwell, R., \& Dodgson, M. (1991). External linkages and innovation in small and mediumsized enterprises. $R \& D$ Management, 21(2), 125-137.

Sandven, T. (1996). Technology acquisition by SMEs in Norway. STEP report R-10 1996. Oslo: STEP Group.

Segelod, E. (1995). Renewal through internal development. Aldershot: Ashgate. 
Segelod, E. (2001) Learning through grafting in ventures in new areas. Scandinavian Journal of Management, 17(3), 135-154.

Sheremata, W.A. (2002). Finding and solving problems in software new product development. Journal of Product Innovation Management, 19(2), 144-158.

Teece, D. J. (1980). Economies of scope and the scope of enterprise. Journal of Economic Behavior and Organization, 1, 223-247.

Thomas, R.J. (1993). New Product Development. New York: John Wiley \& Sons.

Thompson, J.D. (1967). Organizations in Action. New York: McGraw-Hill.

Tidd, J., \& Trewhella, M.J. (1997). Organizational and technological antecedents for knowledge acquisition and learning. R\&D Management, 27(4), 359-375.

Torrisi, S. (1998). Industrial Organisation and Innovation: An International Study of the Software Industry. Cheltenham: Edward Elgar.

Twiss, B. (1974). Managing Technological Innovation. London: Longman Group, Ltd.

Utterback, J.M. (1994). Mastering the Dynamics of Innovation. Boston, MA: Harvard Business School Press.

Veugelers, R., \& Cassiman, B. (1999). Make and buy in innovation strategies: evidence from Belgian manufacturing firms. Research Policy, 28, 63-80.

Wernerfelt, B. (1984). A resource-based view of the firm. Strategic Management Journal, 5(2), 171-180.

Woolgar, S, Vaux, J., Gomes, P., Ezingeard, J.-N., \& Grieve, R. (1998). Abilities and competencies required, particularly by small firms, to identify and acquire new technology. Technovation, 18(8/9), 575-584.

Yli-Renko, H., Autio, E., \& Sapienza, H.J. (2001). Social capital, knowledge acquisition, and knowledge exploitation in young technology-based firms. Strategic Management Journal, 22, 587-613.

Zahra, S.A., \& Bogner, W.C. 1999. Technology strategy and software new ventures' performance: Exploring the moderating effect of the competitive environment. Journal of Business Venturing, 15(2), 135-173.

Zahra, S.A., \& George, G. (2002). Absorptive capacity: A review, reconc eptualization, and extension. Academy of Management Review, 27(2), 185-203. 